Article

\title{
Importance of the Induced Recharge Term in Riverbank Filtration: Hydrodynamics, Hydrochemical, and Numerical Modelling Investigations
}

\author{
Rudy Rossetto ${ }^{1, *}{ }^{\circledR}$, Alessio Barbagli ${ }^{1}\left(\mathbb{D}\right.$, Giovanna De Filippis ${ }^{1}\left(\mathbb{0}\right.$, Chiara Marchina ${ }^{1}(\mathbb{D}$, \\ Thomas Vienken ${ }^{2}$ and Giorgio Mazzanti ${ }^{3}$ \\ 1 Institute of Life Sciences, Scuola Superiore Sant'Anna, 56127 Pisa, Italy; barbagli@cgt-spinoff.it (A.B.); \\ giovanna.df1989@libero.it (G.D.F.); chiara.marchina@unipd.it (C.M.) \\ 2 Helmholtz Centre for Environmental Research GmbH-UFZ, Permoserstraße 15, 04318 Leipzig, Germany; \\ thomas.vienken@ufz.de \\ 3 Genio Civile Toscana Nord, Regione Toscana, 55100 Lucca, Italy; giorgio.mazzanti@regione.toscana.it \\ * Correspondence: rudy.rossetto@santannapisa.it
}

Received: 31 October 2020; Accepted: 5 December 2020; Published: 8 December 2020

\begin{abstract}
While ensuring adequate drinking water supply is increasingly being a worldwide challenging need, managed aquifer recharge (MAR) schemes may provide reliable solutions in order to guarantee safe and continuous supply of water. This is particularly true in riverbank filtration (RBF) schemes. Several studies aimed at addressing the treatment capabilities of such schemes, but induced aquifer recharge hydrodynamics from surface water bodies caused by pumping wells is seldom analysed and quantified. In this study, after presenting a detailed description of the Serchio River RBF site, we used a multidisciplinary approach entailing hydrodynamics, hydrochemical, and numerical modelling methods in order to evaluate the change in recharge from the Serchio river to the aquifer due to the building of the RBF infrastructures along the Serchio river (Lucca, Italy). In this way, we estimated the increase in aquifer recharge and the ratio of bank filtrate to ambient groundwater abstracted at such RBF scheme. Results highlight that in present conditions the main source of the RBF pumping wells is the Serchio River water and that the groundwater at the Sant'Alessio plain is mainly characterized by mixing between precipitation occurring in the higher part of the plain and the River water. Based on chemical mixing, a precautionary amount of abstracted Serchio River water is estimated to be on average $13.6 \mathrm{Mm}^{3} /$ year, which is $85 \%$ of the total amount of water abstracted in a year $\left(\sim 16 \mathrm{Mm}^{3}\right)$. RBF is a worldwide recognized MAR technique for supplying good quality and reliable amount of water. As in several cases and countries the induced recharge component is not duly acknowledged, the authors suggest including the term "induced" in the definition of this type of MAR technique (to become then IRBF). Thus, clear reference may be made to the fact that the bank filtration is not completely due to natural recharge, as in many cases of surface water/groundwater interactions, but it may be partly/almost all human-made.
\end{abstract}

Keywords: drinking water supply; water supply scheme; surface water/groundwater interactions; managed aquifer recharge; induced riverbank filtration; groundwater resource management

\section{Introduction}

Ensuring adequate drinking water supply is one of the most pressing needs for our societies [1]. However, finding reliable sources is more and more a difficult task because of the widespread deterioration of surface water resources (and the related costs for treatment) and groundwater 
deterioration and overexploitation [2-4]. In this sense managed aquifer recharge (MAR) schemes may provide reliable solutions in order to guarantee safe and continuous supply of water [5-7]. Managed aquifer recharge consists in the intentional recharge of aquifers using excess water in wet periods, or non-conventional water sources while at the same time assuring adequate protection of the environment and human-health [8]. Several techniques (spreading methods, Aquifer Storage and Recovery, Soil Aquifer Treatment systems, etc.) have been devised and widely adopted at global scale in the last 60 years [5,9]. Among these, riverbank filtration (RBF) has been in use since about two centuries, being a popular way to tap surface water ensuring at the same time adequate water treatment [10].

RBF is a technique in which the bed and bank of a river serve as treatment zone for the induced river water [10-14], when pumping wells are placed adjacently to a surface water body with continuous and adequate discharge or storage (such as rivers, lakes or basins). As such pumped groundwater in RBF schemes is constituted by a mix of ambient groundwater and induced surface water recharge. Several Authors (i.e., $[11,15,16])$ well-stated that while groundwater quality depends on the land use in the catchment area, bank filtrate quality is a function of river water quality and the efficiency of the purification processes during RBF. Moreover, other studies discuss the treatment capabilities of the RBF MAR systems in dealing with common surface water contaminants, but also with organics and emerging contaminants [17-20]. At the same time, while many examples exist in literature in evaluating surface- and groundwater interactions, at different spatial scales [21] with a number of methods [22], still induced recharge hydrodynamics is seldom analysed and quantified. Sottani and Vielmo (2014) [23] evaluated the extent and the rate of the recharge effects in groundwater due to weir realization in the middle Brenta River plain (Italy). Wei-shi et al. (2020) [24] evaluated the impact of a river reach restoration on the groundwater flow on bank filtration by using a transient flow and heat transport numerical model. Shankar et al. (2009) [15] quantified the contributing ratio of bank filtrate to ambient groundwater by means of a transient numerical model simulation at Grind well field (Germany).

The assessment of the induced recharge and of the ratio of bank filtrate to ambient groundwater is then important as it may provide relevant insights on the risk of groundwater contamination at the RBF wells. As such, in this study, we applied a multidisciplinary approach entailing hydrodynamics, hydrochemical and numerical modelling methods in order to evaluate the change in recharge from the Serchio river (Lucca, Italy) to the aquifer due to the building of the RBF infrastructures along the river. In this way, we estimated the increase in aquifer recharge and the ratio of bank filtrate to ambient groundwater abstracted at such RBF scheme.

\section{Materials and Methods}

The Serchio Riverbank Filtration scheme in Sant'Alessio (Lucca, Italy) supplies an average volume of $16 \mathrm{Mm}^{3}$ /year of drinking water (data from years 2016-2019; source GEAL SpA, local water utility) to about 300,000 citizens of Lucca, Pisa, and Livorno. This plant can be considered an exemplary site for MAR RBF systems. As a blue infrastructure, it provides ecosystem services such as "water storage" and "water quality improvement" [25].

The RBF scheme is set along the Serchio River (Figure 1). Groundwater is tapped by Holocene coarse sand and gravel aquifer overlain by a silty surficial cover. Water is pumped by twelve vertical wells (four at the Sant'Alessio pumping station and eight of the Pisa-Livorno water supply scheme), located between $30 \mathrm{~m}$ and $100 \mathrm{~m}$ from the river reach, inducing river water into the high yield $\left(10^{-2} \mathrm{~m}^{2} / \mathrm{s}\right.$ transmissivity on average [26]) sand and gravel aquifer. The aquifer storage is then increased by the presence of one weir downstream the well field (Figure 2) to raise the river head of about $1.5 \mathrm{~m}$, therefore raising the saturated part of the aquifer along the river reach. 


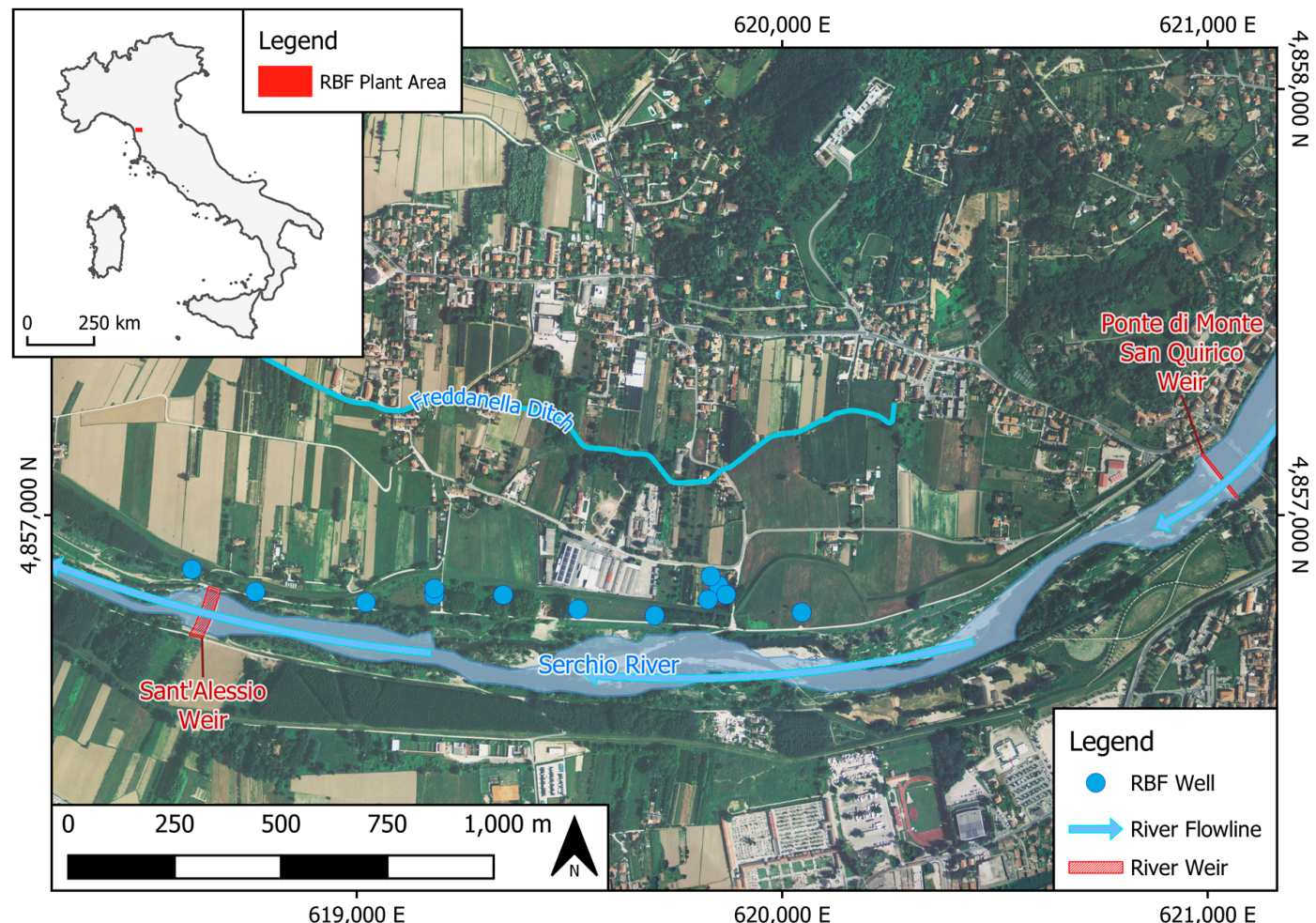

Figure 1. Layout of the Serchio River riverbank filtration scheme in Lucca, Italy. Coordinates are in WGS84-UTM zone 32N (EPSGr: 32632).

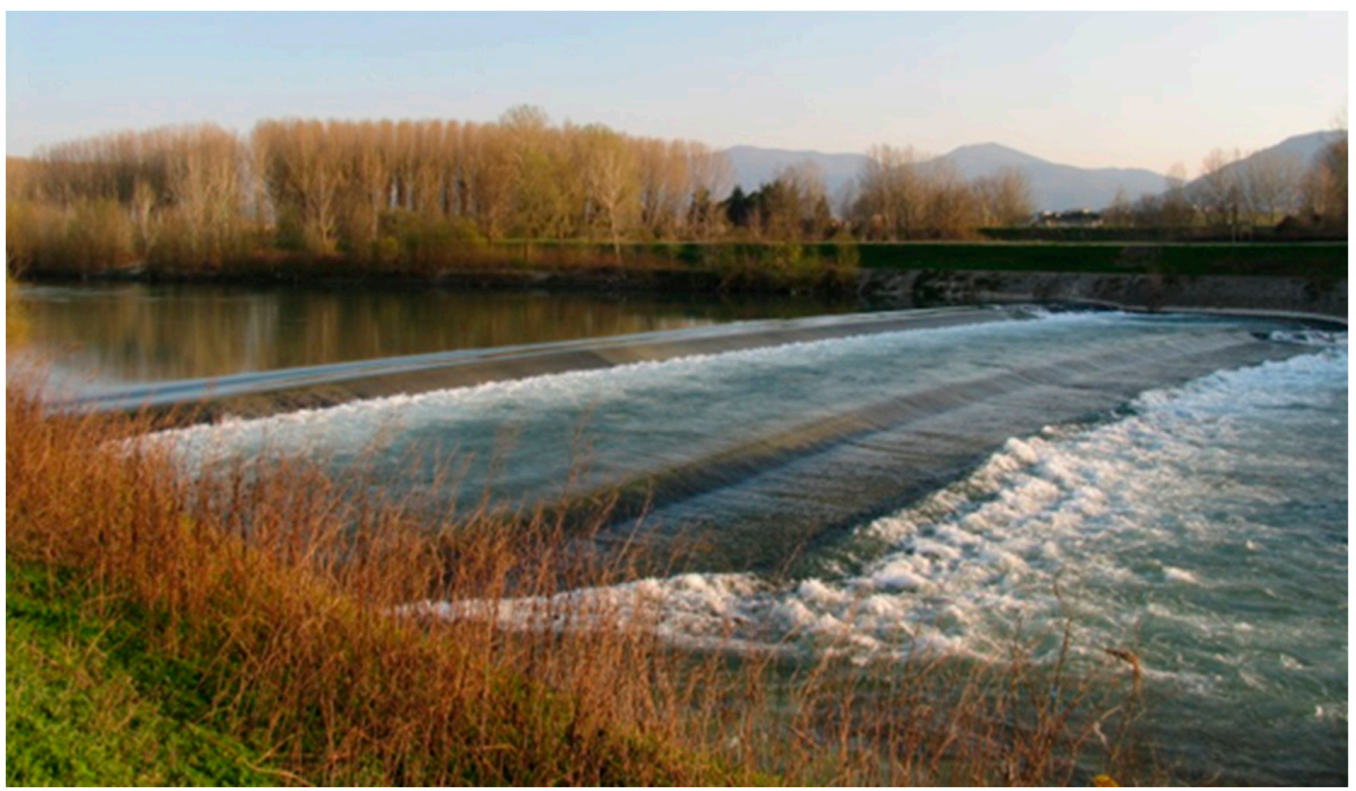

Figure 2. The Sant'Alessio weir on the Serchio River.

Since the 1960s, the Sant'Alessio area along the Serchio River was deemed suitable for groundwater abstraction for drinking water purposes and, initially, four vertical wells were set in operation in 1967. They were drilled about $100 \mathrm{~m}$ away from the Serchio River to supply the north western households of the Lucca town with about $0.1 \mathrm{~m}^{3} / \mathrm{s}$ [27]. Following hydrogeological investigations, in the 1980s a highly yielding sand and gravel aquifer capable of supplying the towns of Pisa and Livorno, about $20 \mathrm{~km}$ and $40 \mathrm{~km}$ away, respectively, was identified. At the end of the 1980s, an Expert Commission evaluated the potential impacts of increasing abstractions and of the building of a weir to increase aquifer storage. 
During the following ten years, the full MAR scheme was completed with the building of the river weir in Sant'Alessio, and it reached a total of about $0.500 \mathrm{~m}^{3} / \mathrm{s}$ supply capacity. More information on the historical development and the socio-economic importance of the Serchio river MAR scheme may be found in Rossetto et al. 2020a [28].

\subsection{Site Description}

The Sant'Alessio plain surface geology is characterized by unconsolidated silty to sandy sediments covering a sandy-gravel aquifer (Figure 3). The aquifer is limited at the bottom by a level of silty clays of lacustrine origin, which outcrops as stiff clays in the northern part of the area. From the Serchio river (south) towards the San Quirico-Carignano hills (north) the silty-sandy cover of the aquifer becomes thinner, going from 6.5-7 $\mathrm{m}$ to less than $1 \mathrm{~m}$ (Figure 3 Bottom). According to Rossetto and Bockelmann-Evans (2007) [29], also the aquifer thickness follows the same trend, starting from about $30 \mathrm{~m}$ in the Serchio riverbed and pinching-out towards the San Quirico-Carignano hills, where the silty-sandy cover directly meets the clay sediments at the aquifer bottom (Figure 3 Top). The Serchio river shows variable discharge ranging from more than $1000 \mathrm{~m}^{3} / \mathrm{s}$ during extreme rainfall events down to few $\mathrm{m}^{3} / \mathrm{s}$ during the summer season in extreme dry years. In the Serchio riverbed the aquifer is covered by coarse and clean gravels outcrops, as well as sand bars.
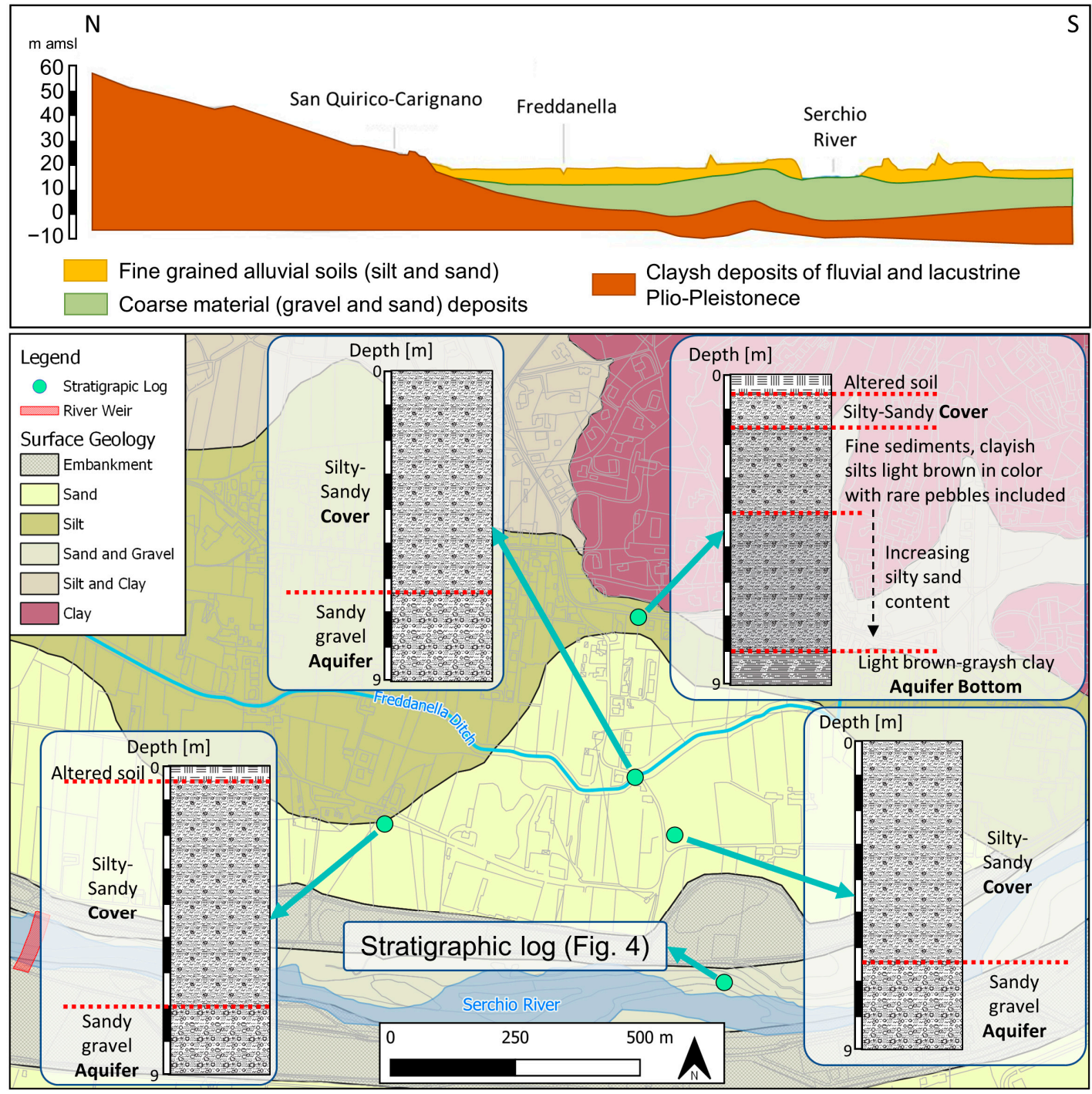

Figure 3. Simplified stratigraphic cross section (top) and detailed stratigraphic logs around the Serchio River RBF area (bottom). 
Outcrops along the Serchio river show a strong contrast in the sedimentological composition of the river deposits which may lead to changes in hydraulic properties over several orders of magnitude on short vertical distances. The vertical heterogeneity of the aquifer was further investigated by a $17 \mathrm{~m}$ deep core drilled directly in the riverbed during a low-flow period (December 2015; Figure 4). According to the drilled core, the river bed stratigraphy was then reconstructed as follows (from the top of the river bed): 0-2 m gravels and sand, 2-5 m sand with gravel in a weakly silty matrix, 5-9.5 m gravel and medium sand in fine matrix, 9.5-12 m gravel in a silty-sandy matrix, 12-15.50 m gravel and sand, $15.50-17.3 \mathrm{~m}$ silty compacted clay.

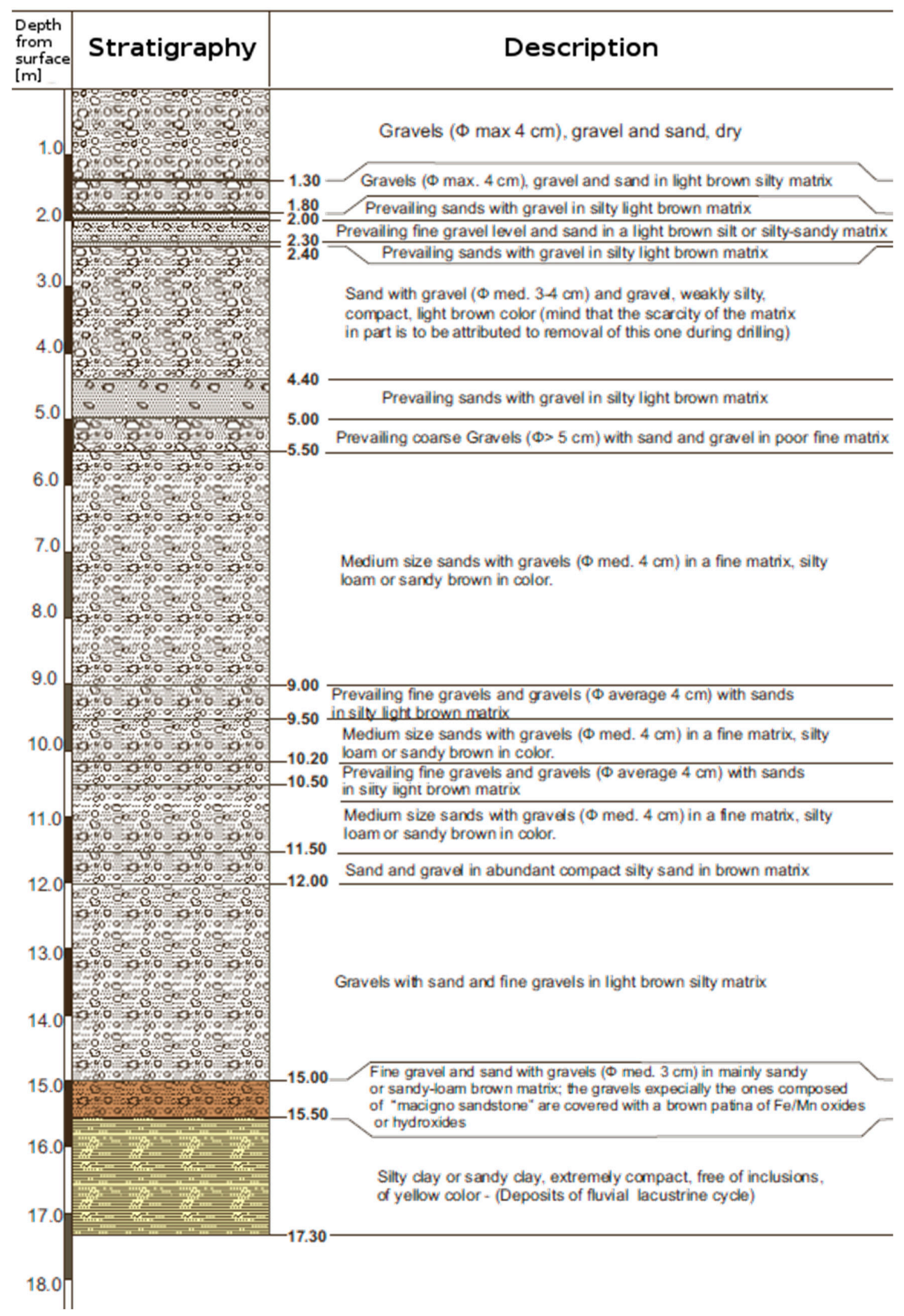

Figure 4. Stratigraphic log from the top of the Serchio river riverbed down to about $17 \mathrm{~m}$. 


\subsection{Hydrodynamic Investigations}

Investigations of the aquifer properties were performed during different campaigns. The first campaign was performed to characterize the aquifer structure in vertical and horizontal extent around the most western RBF well (Figure 1), with a special focus placed on the characterization of subsurface heterogeneity. The successive field campaigns aimed at characterizing the flow field in the vicinity of this pumping well. Direct Push technology, which describes an approach of pushing, hammering, and/or vibrating small-diameter hollow steel rods into the ground [30], was employed during the site investigation to install groundwater monitoring wells and to collect vertical high resolution subsurface information. The latter are obtained using specialized probes that are attached to end of the Direct Push rod string [31-36].

In this study, the Direct Push Injection Logger (DPIL) was used together with Direct Push electrical conductivity logging. The DPIL is used for vertical in-situ hydrostratigraphic profiling as it allows vertical differentiation of units with different hydraulic properties, measured as relative hydraulic conductivity (KDPIL), a parameter that can be linked to absolute hydraulic conductivity [35]. DPIL measurements were performed in vertical steps of $0.4 \mathrm{~m}$; see [37] for detailed information on the tool and data analysis routines. In contrast, Direct Push electrical conductivity was employed for vertical high resolution identification of clay containing, confining layers or lenses as an increase in subsurface electrical conductivity can be related to an increase of clay mineral content under non-saline conditions; see $[33,38]$ for further information. Thirteen DPIL profiles as well as 10 Direct Push electrical conductivity logs were collected during the initial site investigation campaign.

Several tracer tests were additionally performed to characterize the flow field in the vicinity of the pumping well. Tracer test included heat tracer as well as salt tracer testing; the latter was combined with Direct Push electrical conductivity logging for enhanced in-situ monitoring, following the approach of Vienken et al. (2017) [39].

From the hydrodynamic point of view, three main flow directions are converging to the RBF plant (Figure 5): (i) a flow from the alluvial plain northern boundary (San Quirico-Carignano hills) given by the local meteoric recharge infiltrating through low-permeability deposits (from north to south flow) and then infiltrating in the aquifer; (ii) from east to west and from south to north flows. During the year, no seasonal changes are affecting these main flows directions given by the Serchio River filtration into the aquifer. The presence of vertical upward groundwater flow was tested by means of multi-level piezometers, but no relevant vertical gradient was highlighted. The piezometric level at the well field shows a direct relationship with the Serchio river stage, with the range between the maximum and minimum groundwater head no larger than $2 \mathrm{~m}$ between 2011 and 2016 (Figure 6).

River discharge measurements were performed in May 2015 in the Serchio river at two cross-sections corresponding to the 2 weirs (Figure 1), measuring the flow speed with an acoustic flow meter (acoustic digital current meter, OTT Messtechnik $\mathrm{GmbH}$ ) every $50 \mathrm{~cm}$ along three verticals.

\subsection{Hydrochemical Characterisation}

Surface water and groundwater sampling campaigns for hydrochemical characterization were repeated both in dry (2 campaigns from May 2015 to October 2015 and 3 from May 2016 to October 2016) and in wet (2 campaigns from November 2015 to April 2016) periods. Data were collected from 25 different sampling points (including multilevel piezometer clusters at point PR_01-02-03-04-05-06) to assess hydrochemical seasonal variability. Groundwater samples were mostly collected using a low-flow pump after purging at least three well volumes and reaching stable values of the chemical-physical parameters monitored during sampling (Temperature, Electric Conductivity, Redox Potential, and Dissolved Oxygen). Surface water samples were collected $30 \mathrm{~cm}$ below the water surface, where the flow was sufficiently high to guarantee a representative sample. Sampling campaigns for isotopic characterization were performed on a selected sub sample of the monitoring points (14 in total) and on 2 different periods: dry season (May 2015) and wet season (January 2016). 


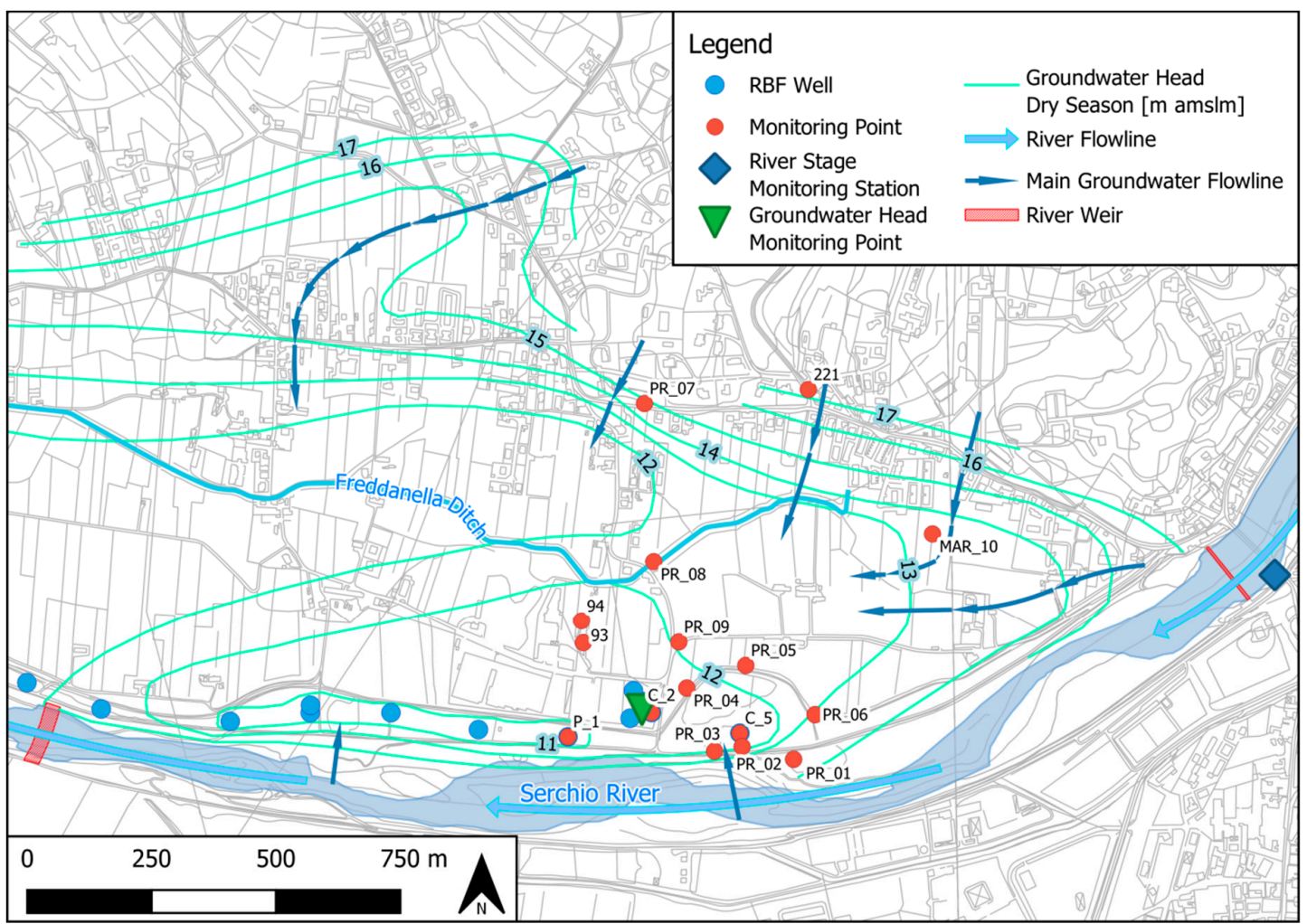

Figure 5. Monitoring network (groundwater head and hydrochemistry) in relation to the main groundwater flow directions. Piezometric head data from September 2003 (dry season; data from Studio Nolledi 2003).

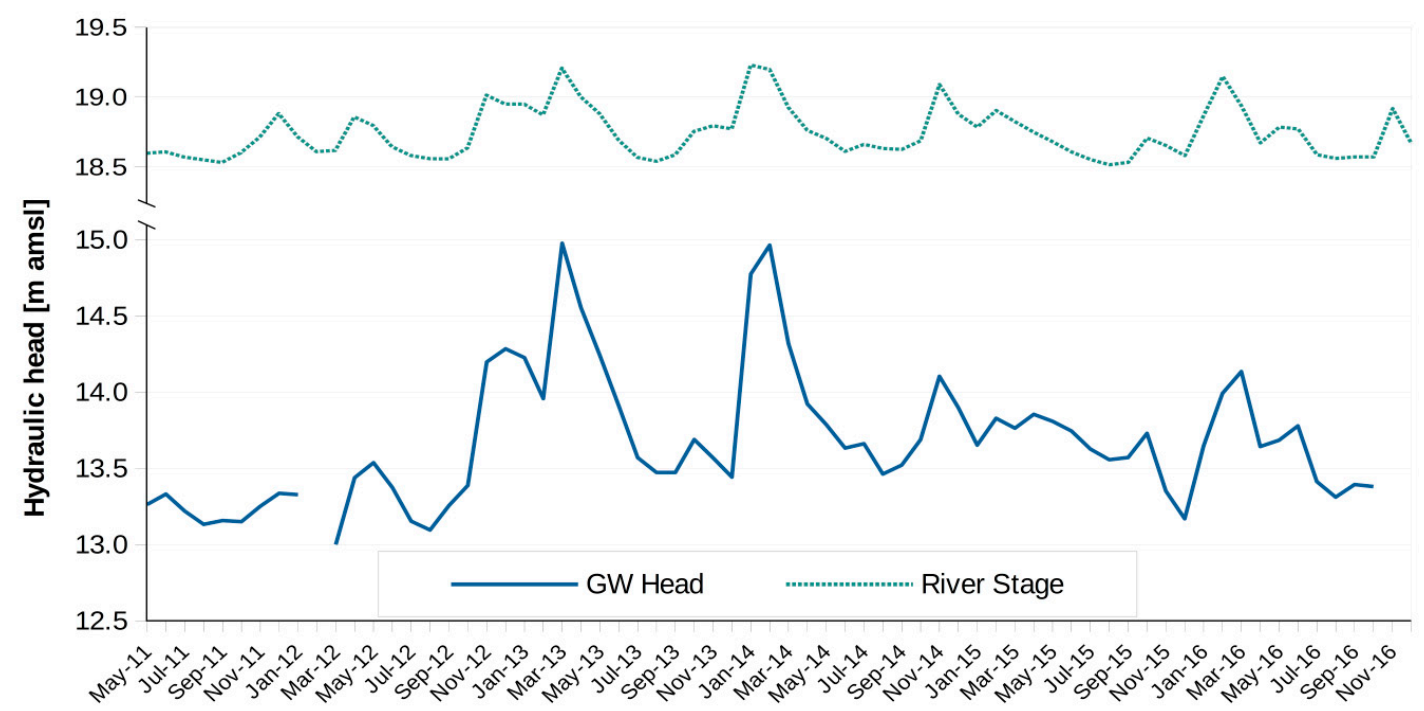

Figure 6. Monthly groundwater head data at the Serchio River RBF plant and Serchio river stage at the Ponte di Monte San Quirico monitoring station from May 2011 to December 2016 (data courtesy of Servizio Idrologico Regionale-Regione Toscana). The locations of the piezometer and the Serchio river monitoring station are marked in Figure 4.

Water samples were filtered by $0.45 \mu \mathrm{m}$ filters (Minisart ${ }^{\circledR}$ NML syringe cellulose acetate filters) and separated in different aliquots. $50 \mathrm{~mL}$ PE bottles were taken for the analysis of anions and oxygen/hydrogen isotopes in each site. An additional $50 \mathrm{~mL}$ PE bottle (acidified with $0.5 \mathrm{~mL}$ of concentrated Suprapur $\mathrm{HNO}_{3}$ ) was taken for the determination of cations and trace elements. After sampling all the aliquots were stored at $4{ }^{\circ} \mathrm{C}$ until analyzed. 
Cations and trace elements were measured by inductively coupled plasma mass spectrometry (ICP-MS) using a Thermo-Scientific X Series instrument (Thermo, Bremen, Germany). The samples were previously diluted 1:10 by deionized Milli-Q water (resistivity of ca. $18.2 \mathrm{M} \Omega \times \mathrm{cm}$ ) and a known amount of Re and Rh have been introduced as internal standard; in each analytical session. The analysis of samples was verified with that of the reference materials EU-L-1 and ES-L1 provided by SCP-Science (www.scpscience.com).

Anions were determined by ion chromatography using a Dionex ICS-1000 (Thermo, Bremen, Germany), calibrated by different dilutions of the Dionex "7-ion standard". The coherence of chemical data was verified by checking the ionic balance, as the sum of cation (expressed in meq/L) approaches that of anions with a relative error less than $5 \%$. Hydrogen and oxygen isotope ratios were determined using the CRDS Los Gatos LWIA 24-d isotopic analyzer (Los Gatos Research, California, USA). The isotopic ratios of ${ }^{2} \mathrm{H} /{ }^{1} \mathrm{H}$ and ${ }^{18} \mathrm{O} /{ }^{16} \mathrm{O}$ are expressed as $\delta$ notation $[\delta=(($ Rsample/Rstandard $)-1) \times 1000]$ with respect to the Vienna Standard Mean Ocean Water (VSMOW) international standard. Four bracketing standards were run throughout the analytical sessions, as indicated in Marchina et al. (2020) [40].

\subsection{Groundwater Flow Numerical Modelling}

A groundwater flow numerical model was built by means of the FREEWAT software [41,42] using the MODFLOW-2005 code [43]. FREEWAT, as its predecessor SID\&GRID [44], is a free and open source platform, QGIS-integrated, for planning and management of ground- and interactions with surface-water resources. It is the main result of the HORIZON 2020 FREEWAT project (FREE and open source software tools for WATer resource management [45]). FREEWAT provides tools for archiving, analyzing and processing the groundwater data and information (e.g., sensor and field data on groundwater levels and hydrochemical data) along with post-processing tools for visualization and analysis of the model results [46,47]. MODFLOW is one of the codes most widely used in the world for numerical simulation of groundwater flow in aquifers. It solves the groundwater flow equation in three dimensions using a finite difference scheme. The FREEWAT software has been applied at several case studies; details may be found in, i.e., [48,49].

We simulated an active domain extending over $4.2 \mathrm{~km}^{2}$ discretized using square cells $100 \mathrm{~m}^{2}$ wide and two model layers, a silty-sandy superficial cover and the sandy-gravelly aquifer. The conceptual model for the simulated domain is shown in Figure 7. The northern boundary of the active domain, corresponding to the outcrop of impervious clayey sediments of the Monte S. Quirico-Carignano hills, was defined according to the geological setting of the area (Figure 3). Hydraulic connection with the Serchio river and exploitation of the aquifer through the Sant'Alessio well field were simulated. The model has been implemented to simulate two years, from 20 November 2014 until 30 November 2016. The simulation started with a steady-state stress period lasting 11 days, and then with 24 transient monthly stress periods. Calibration was run using a mixed trial and error and automatic parameter estimation approach [50]. Details and more information on the model implementation may be found in Rossetto et al. (2017) [51].

The calibrated model was then used to simulate the evolution of the RBF scheme in order to evaluate the change in recharge from the Serchio river to the aquifer. The following scenarios were simulated:

(a) Simulation of the aquifer river exchange prior to any riverbed modification or aquifer exploitation in order to evaluate pristine conditions: to this aim, we linearly reconstructed the riverbed profile prior to the weir construction;

(b) Simulation of the aquifer river exchange prior to any riverbed modification considering aquifer exploitation for $0.350 \mathrm{~m}^{3} / \mathrm{s}$;

(c) Simulation of the aquifer river exchange considering the Sant'Alessio weir in operation and aquifer exploitation for $0.350 \mathrm{~m}^{3} / \mathrm{s}$;

(d) Simulation of the aquifer river exchange considering the Sant'Alessio weir in operation and aquifer exploitation for $0.430 \mathrm{~m}^{3} / \mathrm{s}$. 


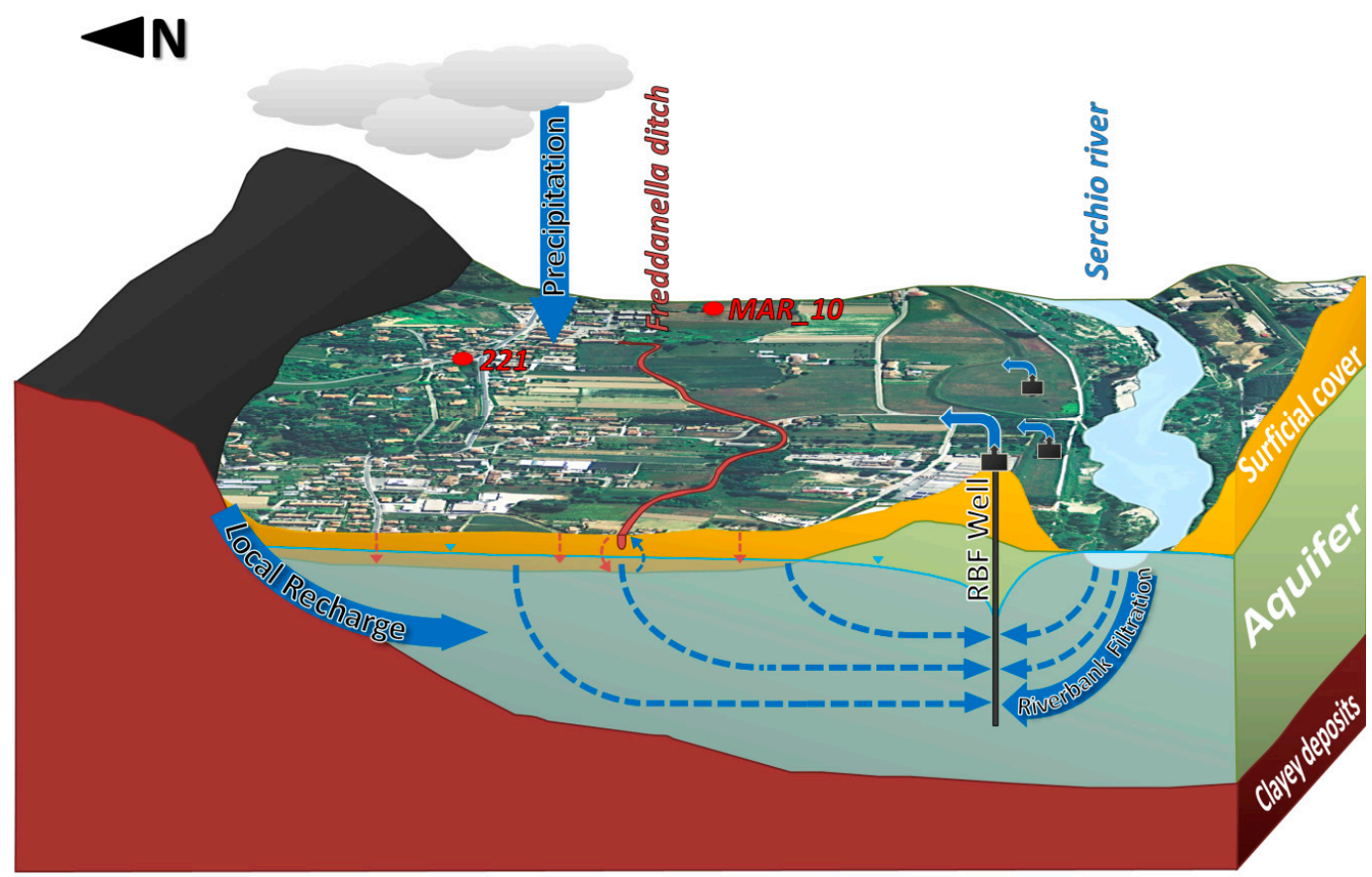

Figure 7. Conceptual model for the simulated domain; main hydrological elements are shown.

\section{Result and Discussion}

In order to answer the research questions, we jointly used the results of the performed analysis to provide data for the definition of the conceptual model and for the implementation of the numerical modelling (i.e., data coming from the hydrodynamic investigations) or to cross-validate the results of each approach.

Results from the hydrodynamics investigations informed the implementation of the numerical model and provided additional insights on the groundwater flow field. DPIL measurements revealed a strong variation of DPIL values on short vertical distances within the aquifer, while measured electrical conductivity values showed only minor variation, ranging between $10 \mathrm{mS} / \mathrm{m}$ and $20 \mathrm{mS} / \mathrm{m}$. These are typical values for clean sands and gravels. Figure 8 depicts Direct Push logging results at an investigation point located approximately $90 \mathrm{~m}$ north-east of the pumping well C5 (Figure 5). Based on the results, the identification of hydrostratigraphic units or prevailing layers within the aquifer itself was not possible. Hence, Direct Push based pneumatic slug testing (see [52]) was performed at four locations in proximity of the pumping well C5 at different depth intervals between 3.6 and $10 \mathrm{~m}$ below ground surface to obtain further information on the distribution of hydraulic conductivity. Measured values ranged between $5.6 \times 10^{-3} \mathrm{~m} / \mathrm{s}$ and $3.3 \times 10^{-4} \mathrm{~m} / \mathrm{s}$.

Thanks to the tracer tests a maximum bulk groundwater flow velocity of $26 \mathrm{~m} / \mathrm{d}$ was estimated based on the first arrival times of the sodium-chloride tracer test breakthrough curve measurement. Despite the use of vertical high-resolution exploration, it was not possible to resolve the aquifer heterogeneity and to obtain in-depth understanding of the hydrodynamics using field investigations alone. This clearly highlights the necessity to approach experimental complex questions in groundwater hydrology by combining sophisticated site investigation and advanced modelling. 


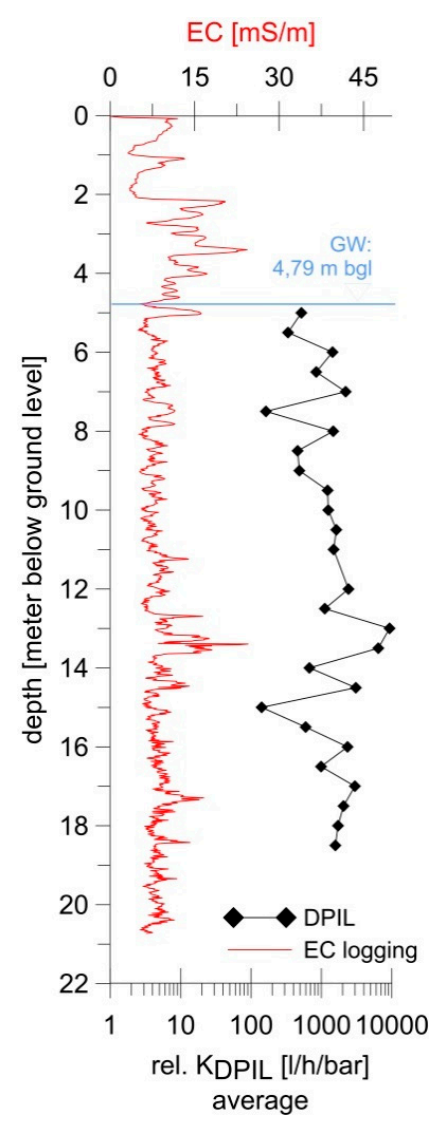

Figure 8. Direct Push profiling results (DPIL and Electrical Conductivity measurements).

The simulated water budget for one hydrological year (October 2015 to September 2016) is presented in Table 1. As far as the inflow terms, the Serchio river recharge constitutes the bulk of aquifer recharge in the Sant'Alessio plain with an overall yearly volume of about $58 \mathrm{Mm}^{3}$, in line with the loss of river water estimated by means of flow measurements $\left(1.4 \mathrm{~m}^{3} / \mathrm{s}\right)$. This recharge occurs within the reach Ponte di Monte San Quirico-Sant'Alessio weir (Figures 1 and 9). A smaller inflow term is constituted by meteoric recharge and inflow from the adjoining hills. Outflows from the systems are dominated by RBF pumping wells abstraction (about $16 \mathrm{Mm}^{3}$ ), outflow from the southern boundary (about $8 \mathrm{Mm}^{3}$ ), and drainage of the aquifer operated by the river south of the Sant'Alessio weir. The effect of the Freddanella ditch in draining the aquifer is negligible. The simulated head contour map (Figure 9) clearly shows this situation, presenting also a large drainage axis at about the middle of the plain.

Table 1. Simulated water budget for the Sant'Alessio aquifer for the hydrologic year October 2015 to September 2016.

\begin{tabular}{lcccc}
\hline & \multicolumn{2}{c}{ Inflow Terms } & \multicolumn{2}{c}{ Outflow Terms } \\
\hline & Cumulative Volume $\left.\mathbf{( m}^{\mathbf{3}}\right)$ & \% Over the Total & Cumulative Volume $\left(\mathbf{m}^{\mathbf{3}}\right)$ & \% Over the Total \\
\hline Storage & 846 & Negligible & 938 & Negligible \\
Inflow from the Monte & 207,089 & 0.3 & $15,640,341$ & 26.4 \\
$\begin{array}{l}\text { S.Quirico-Carignano hills } \\
\text { Rainfall infiltration }\end{array}$ & 673,287 & 1.1 & 658 & Negligible \\
River leakage & $58,154,744$ & 98.2 & $38,439,232$ & 64.9 \\
Southern boundary of & 160,214 & 0.3 & $5,109,272$ & 8.6 \\
the domain & $59,196,180$ & 100.0 & $59,190,432$ & 100.0 \\
\hline \multicolumn{1}{c}{ TOTAL } & & & & \\
\hline
\end{tabular}




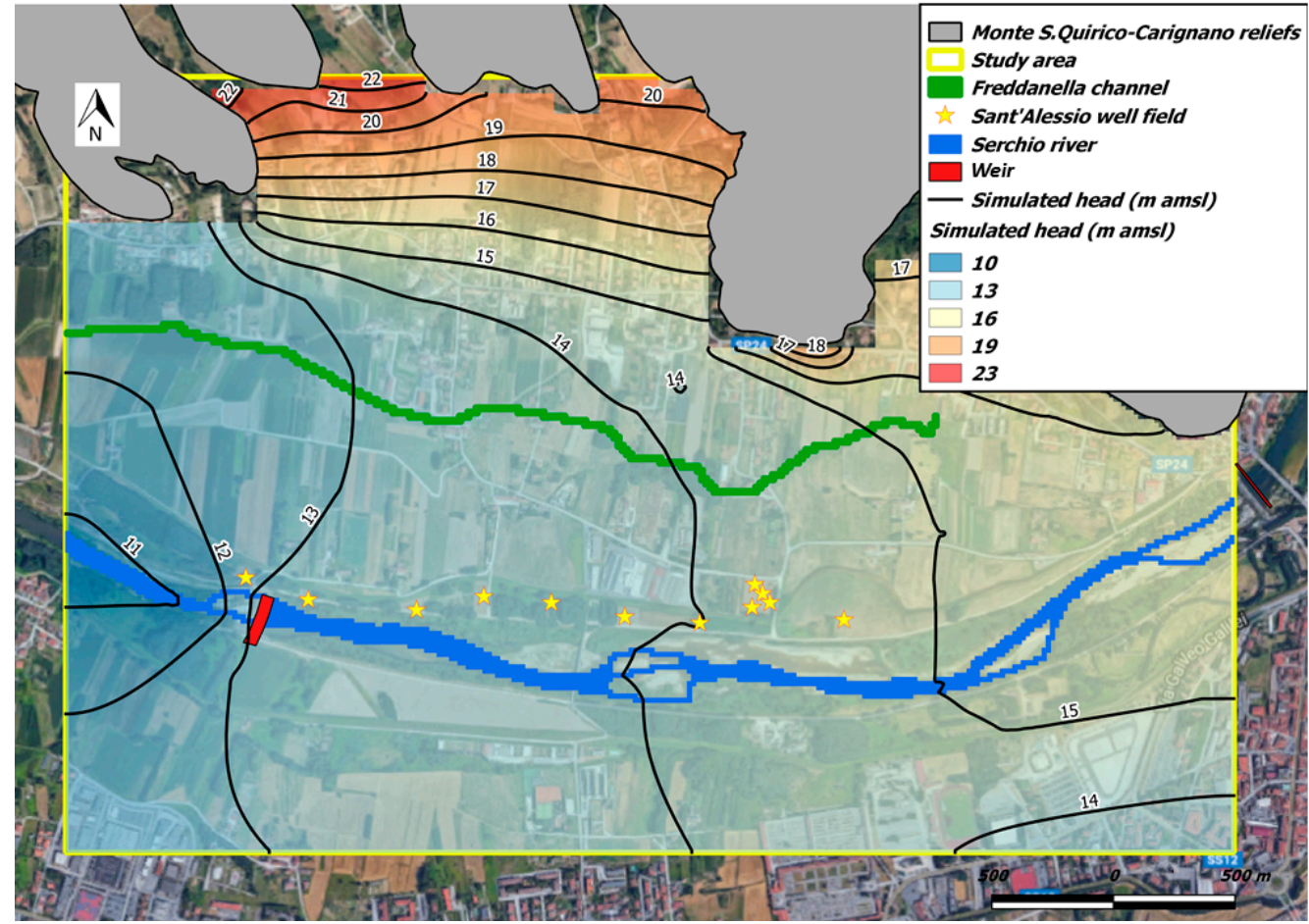

Figure 9. Simulated hydraulic head at the end of May 2016.

Table 2 shows the results of the analyses run in order to evaluate the change in recharge from the Serchio river to the aquifer induced during the evolution of the RBF scheme. In pristine conditions (riverbed not modified and wells not built), simulation results show that the natural recharge of the aquifer was of about $0.150 \mathrm{~m}^{3} / \mathrm{s}$. Construction of the first set of wells and their operation at an overall abstraction rate of $0.350 \mathrm{~m}^{3} / \mathrm{s}$ would have caused an estimated recharge of about $0.490 \mathrm{~m}^{3} / \mathrm{s}$, hence inducing in the aquifer around $0.340 \mathrm{~m}^{3} / \mathrm{s}$. We then estimated in about $0.030 \mathrm{~m}^{3} / \mathrm{s}$ the additional recharge provided as result of the construction in the 1990s of the Sant'Alessio weir. This recharge then creates an additional aquifer storage of about $1 \mathrm{Mm}^{3}$. Finally, increasing groundwater withdrawal up to $0.430 \mathrm{~m}^{3} / \mathrm{s}$ (from initial $0.350 \mathrm{~m}^{3} / \mathrm{s}$ ) induces an additional recharge of about $0.09 \mathrm{~m}^{3} / \mathrm{s}$.

Table 2. Simulated changes in river recharge from pristine conditions to completion of the Serchio River RBF managed aquifer recharge scheme.

\begin{tabular}{|c|c|c|c|}
\hline & No-Weir/No-Wells & No-Weir/Average Pumping $\left(0.350 \mathrm{~m}^{3} / \mathrm{s}\right)$ & Change in Recharge Rate $\left(\mathrm{m}^{3} / \mathrm{s}\right)$ \\
\hline \multirow[t]{2}{*}{ Net Aquifer Recharge $\left(\mathrm{m}^{3} / \mathrm{s}\right)$} & 0.151 & 0.488 & 0.337 \\
\hline & $\begin{array}{c}\text { No-Weir/Average Pumping } \\
\left(0.350 \mathrm{~m}^{3} / \mathrm{s}\right)\end{array}$ & Weir/Average Pumping $\left(0.350 \mathrm{~m}^{3} / \mathrm{s}\right)$ & Change in Recharge Rate $\left(\mathrm{m}^{3} / \mathrm{s}\right)$ \\
\hline \multirow[t]{2}{*}{ Net Aquifer Recharge $\left(\mathrm{m}^{3} / \mathrm{s}\right)$} & 0.488 & 0.521 & 0.033 \\
\hline & $\begin{array}{l}\text { Weir/Average Pumping } \\
\left(0.350 \mathrm{~m}^{3} / \mathrm{s}\right)\end{array}$ & Weir/High Pumping $\left(0.430 \mathrm{~m}^{3} / \mathrm{s}\right)$ & Change in Recharge Rate $\left(\mathrm{m}^{3} / \mathrm{s}\right)$ \\
\hline Net Aquifer Recharge $\left(\mathrm{m}^{3} / \mathrm{s}\right)$ & 0.521 & 0.609 & 0.088 \\
\hline
\end{tabular}

These results show that the increase in recharge induced by pumping is larger than that caused by the weir construction. The latter brought a limited, yet important, change in storage. Figure 10 shows the groundwater head increase in the aquifer after the construction of the Sant'Alessio weir compared to the previous condition, with only the well field in operation. At the RBF scheme, the river/aquifer connection ensures, thanks to Serchio river discharge, stable recharge of the aquifer induced by the pumping wells and by the presence of the river weir. Hence, this also guarantees a limited drawdown of the water table. 


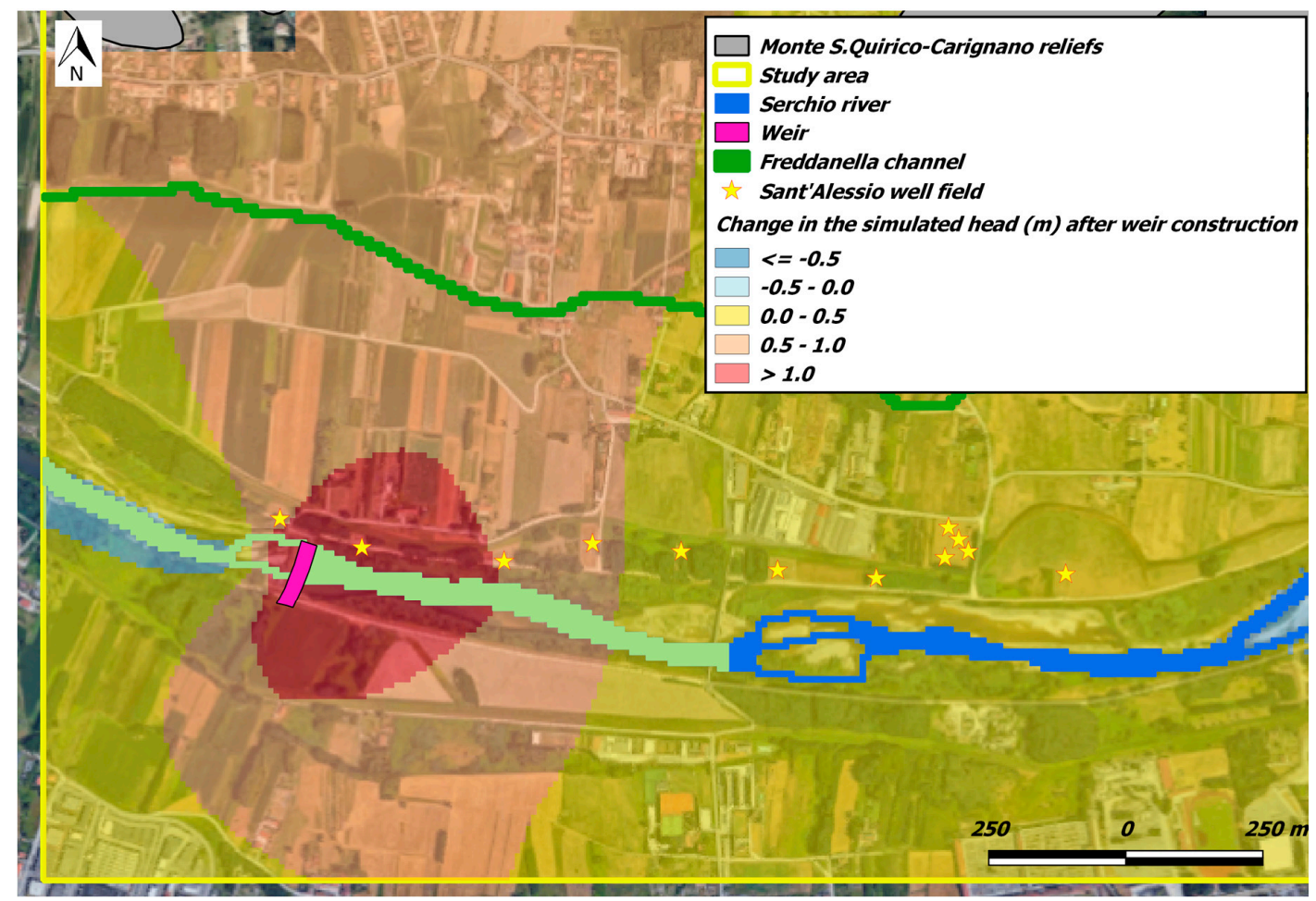

Figure 10. Simulated difference in groundwater head between pre- and post-operam of the Sant'Alessio weir.

As far as water hydrochemistry, according to the Piper classification diagrams (Figure 11 bottom), the samples mainly exhibit a $\mathrm{Na}-\mathrm{K}-\mathrm{HCO}_{3}$ hydrochemical facies with a clear trend towards the $\mathrm{Ca}-\mathrm{Mg}-\mathrm{SO}_{4}$ facies, perfectly aligned on a mixing line from the point 221 to the Serchio river (see Figures 5 and 7). The only exception to this trend is the sample at the "Freddanella" ditch, a canal draining the Sant'Alessio plain and also collecting untreated wastewater, hence to be considered as an end-member for potential groundwater pollution in the conceptual model [53]. This canal did not show any hydrochemical facies predominance during the dry season 2015.

The mixing process between surface water and ambient groundwater is also confirmed by the binary plots of conservative elements such as $\mathrm{Cl}^{-}$and $\mathrm{Br}^{-}$(Figure 11, top right). However, as for the geochemical facies, the mixing process of conservative elements is more pronounced during the dry season, when the chloride content of the Serchio river is not affected by dilution due to rainfall, and, at the same time, the $\mathrm{Cl}^{-}$concentrations are more uniform in the groundwater.

The $\delta^{18} \mathrm{O}$ and $\delta^{2} \mathrm{H}$ values of water are very uniform in most of the samples and they have isotopic values ranging between $-8.2 \%$ ond $-4.9 \%$ o for $\delta^{18} \mathrm{O}$, and $-31.7 \%$ ond $-49 \%$ o for $\delta \mathrm{D}$. These values are plotted in Figure 11 (top left), together with the Global Meteoric Water Line (GMWL) calculated by Rozansky (1993) [54] and the Local Meteoric Water Lines calculated by Longinelli and Selmo (2003) [55] and La Ruffa and Panichi (2000) [56]. The results evidence a trend of precipitation typical for the west coast of Italy. This data is also confirmed by an average deuterium excess of $14.6 \%$, respect the GMWL, which is in the typical range for the northern Tuscan area (10.8-14.6\%o; Longinelli and Selmo, 2003) [55].

Isotopic data describes a clear mixing process between the Serchio river water and the groundwater. The isotopic composition of the local recharge (point 221, in Figures 7 and 11) is the least depleted (in light isotopes, i.e., ${ }^{16} \mathrm{O}$ and ${ }^{1} \mathrm{H}$ ), while the Serchio river reveals an isotopic signature similar to those of the groundwater pumped at the RBF wells. The groundwater in the Sant'Alessio plain and at the RBF plant shows a clear signature characterized by the Serchio river. This River originates in the Apuan Alps catchment (with maximum elevation of about $2000 \mathrm{~m}$ amsl, and average elevation of $717 \mathrm{~m}$ amsl) and therefore shows values more depleted (therefore richer in light isotopes) than the ones 
of the local recharge (originating in the San Quirico-Carignano hills, average elevation $\sim 40 \mathrm{~m}$ amsl). In particular, the point sampled in the Sant'Alessio plain (MAR_10) is placed almost at the middle of the mixing line (Figure 11 left). The mixing processes highlighted by the $\delta^{18} \mathrm{O}$ and $\delta^{2} \mathrm{H}$ can be detected during the dry and, also, the wet season. However, during the wet period, the Serchio river shows an enrichment in heavy isotopes due to the impact of local precipitation and the influence of tributaries from lower sub-catchments in the upstream part of the basin and, at the same time, its influence on the groundwater of the Sant'Alessio plain (also at MAR_10) is higher due to its higher stage and discharge.
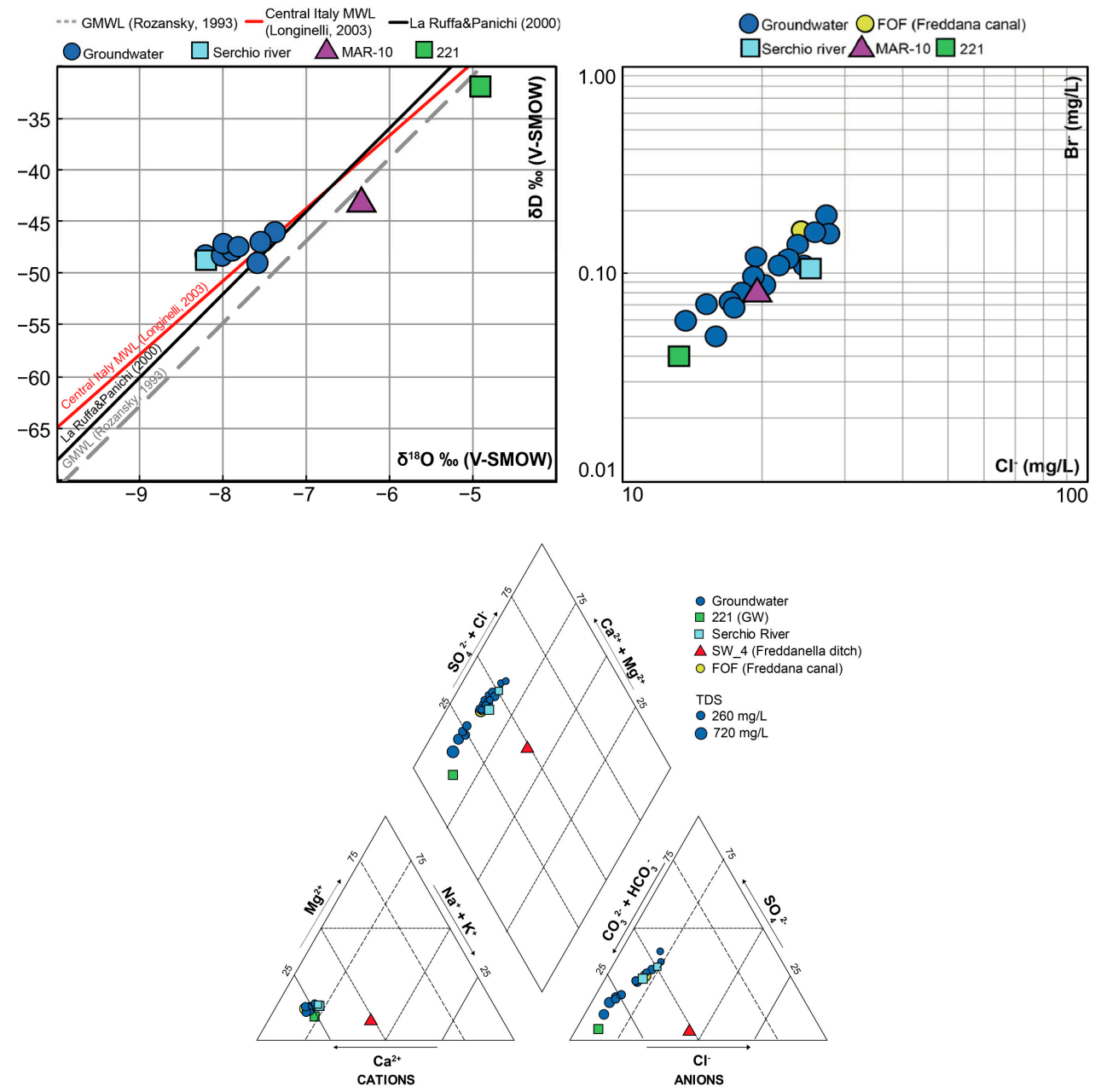

Figure 11. Piper diagram (bottom), $\mathrm{Cl}^{-}$vs $\mathrm{Br}^{-}$binary plot (top right) and $\delta^{18} \mathrm{O}$ vs $\delta^{2} \mathrm{H}$ binary plot (top left) of the samples collected during the dry season of 2015.

Therefore, as suggested both by the hydrodynamic and the hydrochemical data, the Serchio river and the local recharge from the northern part of the aquifer (groundwater entering the aquifer along the northern hilly border) can be considered end-member terms of the mixing system. Based on this assumption, different seasonal mixing fractions were computed using the distribution of lithium as conservative tracer. Lithium is the trace element showing the widest range of values among the end-members in the Sant'Alessio area (with high concentration in the Serchio river and values below the detection limit in the point 221; Table 3). The mixing fractions showed the extension of the Serchio river recharge within the Sant'Alessio aquifer and its importance at the RBF plant (Figure 12). 
Table 3. Average values during dry and wet season of the presented analytes.

\begin{tabular}{|c|c|c|c|c|c|c|c|c|c|c|c|c|c|c|c|c|c|c|c|c|c|c|}
\hline \multirow[b]{2}{*}{ Sampling Point } & \multicolumn{11}{|c|}{ Dry Season } & \multicolumn{11}{|c|}{ Wet Season } \\
\hline & $\begin{array}{c}\mathrm{Na}^{+} \\
\mathrm{mg} / \mathrm{L}\end{array}$ & $\begin{array}{c}\mathrm{K}^{+} \\
\mathrm{mg} / \mathrm{L}\end{array}$ & $\begin{array}{l}\mathrm{Ca}^{2+} \\
\mathrm{mg} / \mathrm{L}\end{array}$ & $\begin{array}{l}\mathrm{Mg}^{2+} \\
\mathrm{mg} / \mathrm{L}\end{array}$ & $\begin{array}{l}\mathrm{HCO}_{3}{ }^{-} \\
\mathrm{mg} / \mathrm{L}\end{array}$ & $\underset{\mathrm{mg} / \mathrm{L}}{\mathrm{Cl}^{-}}$ & $\begin{array}{l}\mathrm{SO}_{4}{ }^{2-} \\
\mathrm{mg} / \mathrm{L}\end{array}$ & $\begin{array}{c}\mathrm{Br}^{-} \\
\mathrm{mg} / \mathrm{L}\end{array}$ & $\begin{array}{c}\mathrm{Li} \\
\mu \mathrm{g} / \mathrm{L}\end{array}$ & $\begin{array}{c}\delta 180 \\
\% o\end{array}$ & $\begin{array}{l}\delta \mathrm{D} \\
\% \text { o }\end{array}$ & $\begin{array}{c}\mathrm{Na}^{+} \\
\mathrm{mg} / \mathrm{L}\end{array}$ & $\begin{array}{c}\underset{\mathrm{K}}{+} \\
\mathrm{mg} / \mathrm{L}\end{array}$ & $\begin{array}{l}\mathrm{Ca}^{2+} \\
\mathrm{mg} / \mathrm{L}\end{array}$ & $\begin{array}{l}\mathrm{Mg}^{2+} \\
\mathrm{mg} / \mathrm{L}\end{array}$ & $\begin{array}{l}\mathrm{HCO}_{3}- \\
\mathrm{mg} / \mathrm{L}\end{array}$ & $\begin{array}{c}\mathrm{Cl}^{-} \\
\mathrm{mg} / \mathrm{L}\end{array}$ & $\begin{array}{l}\mathrm{SO}_{4}^{2-} \\
\mathrm{mg} / \mathrm{L}\end{array}$ & $\begin{array}{c}\mathrm{Br}^{-} \\
\mathrm{mg} / \mathrm{L}\end{array}$ & $\begin{array}{c}\mathrm{Li} \\
\mu \mathrm{g} / \mathrm{L}\end{array}$ & $\begin{array}{c}\delta 180 \\
\% \text { o }\end{array}$ & $\begin{array}{l}\delta \mathrm{D} \\
\% \mathrm{o}\end{array}$ \\
\hline 93 & 97 & 2.23 & 71.42 & 47. & 234 & 16.83 & 55.79 & 0 & 3 & - & - & 16.19 & 2 & 04.90 & 11.34 & 191 & 29.04 & 03.31 & 0.16 & 7.63 & - & - \\
\hline 94 & & & & 10 & & 10 & & & 400 & - & - & - & 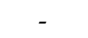 & - & . & 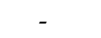 & - & 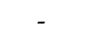 & 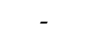 & 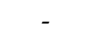 & 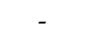 & - \\
\hline 221 & 35 & 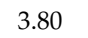 & 67 & 4.59 & 249 & 20.85 & 14.67 & 0.11 & 0.77 & -4.9 & -31.7 & 14.45 & 3.85 & 69.84 & 5.42 & 270 & 22.67 & 10.48 & 0.14 & 0.74 & -5.0 & -30.6 \\
\hline C_2 & 67 & 1.60 & 68.32 & 9.5 & 164 & 26.15 & 97.05 & 0.1 & 11.66 & - & 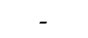 & 19.05 & 1.62 & 83.55 & 10.53 & 150 & 27.00 & 98.88 & 0.13 & 13.30 & -6.7 & -46.6 \\
\hline C_5 & 30 & 1.55 & 69.45 & 9.44 & 155 & 31.54 & 101.77 & 0.11 & 12.29 & -7.9 & -47.6 & 17.82 & 1.55 & 4.93 & 9.07 & 144 & 27.38 & 103.87 & 0.13 & 13.13 & -6.4 & -43.7 \\
\hline MAR_1 & 16 & 2.18 & 63.30 & 10.09 & 320 & 24.42 & 91.97 & 0.0 & 7.93 & -6.3 & -43.3 & 21.39 & 2.8 & 117.27 & 13.84 & 224 & 28.93 & 80.76 & 0.10 & 10.32 & -6.8 & -42.3 \\
\hline P_t & 73 & 65 & 71.88 & 9.73 & 162 & 29.58 & 116.05 & 0.14 & 13.21 & - & - & 22.63 & 1.42 & 6.18 & 12.01 & 140 & 42.87 & 129.96 & 0.28 & 15.22 & - & - \\
\hline PR_01 & .77 & 1.98 & 74.06 & 9.24 & 162 & 33.49 & 101.05 & 0.1 & 13.2 & -8 & -48 & 16.62 & 1.37 & 79.39 & 10.26 & 120 & 27.80 & 102.04 & 0.18 & 12.31 & -7.2 & -44.0 \\
\hline P & & , & & & & 1 & 60.80 & 0.0 & 9.29 & -7.4 & -45.7 & - & & & & 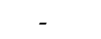 & - & & & 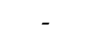 & - & - \\
\hline $\mathrm{P}$ & 06 & 1. & 7.14 & & 159 & 19.95 & 62.98 & 0.0 & 12.22 & -7.8 & -47.3 & 20.40 & 1.37 & 3.29 & 10.5 & 174 & 30.66 & 110.71 & 0.21 & 12.02 & -7.0 & -44.0 \\
\hline P & & 148 & 59.21 & & 209 & 20.25 & 62.65 & 0.1 & 10.91 & -8.0 & -47.1 & 19.77 & 1.48 & 8087 & 10.79 & 155 & 32.91 & 126.16 & 0.20 & 14.78 & -7.2 & -43.7 \\
\hline PR_02 & 77 & 1.7 & 67.90 & 9.0 & & 25.69 & 99.80 & 0. & 13 & -8 & -48.2 & 21.02 & 1.78 & 78.75 & 11.63 & 127 & 33.23 & 125.07 & 0.34 & 13.89 & 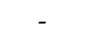 & . \\
\hline & & & & 7.6 & & & 67.20 & & 1 & -7 & & 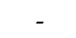 & 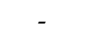 & 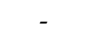 & 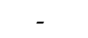 & 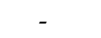 & 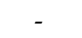 & & 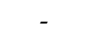 & - & - & - \\
\hline $\mathrm{P}$ & 70 & 1.74 & 57.40 & 7.6 & 1 & 21.67 & 69.99 & 0. & 9. & -7.6 & -46.9 & 18.97 & 1.64 & 79.04 & 10.37 & 143 & 32.99 & 119.66 & 0.17 & 9.99 & - & - \\
\hline P & 41 & 1.54 & 61.04 & 8. & 159 & 24.05 & 72.62 & & 11. & -7.6 & -49.0 & 20.14 & 1.65 & 83.55 & 10.78 & 153 & 31.09 & 122.80 & 0.14 & 13.02 & -7.2 & -46.1 \\
\hline & & 1 & & & & 27.24 & 81. & & 11. & -7.5 & -46.7 & - & 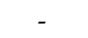 & 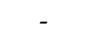 & - & - & - & 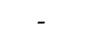 & - & - & - & . \\
\hline & 89 & 1.34 & 52.22 & 8. & 135 & 20.72 & 58.03 & 0. & 10.1 & - & - & 19.4 & 1.5 & 7.18 & 10.3 & 231 & 31.89 & 21.68 & 0.18 & 12.20 & -7.5 & -46.6 \\
\hline PR_0 & 14.03 & 1.24 & 59.17 & 8. & 178 & 18.88 & 68.47 & & 8.0 & - & - & 19.98 & 1.99 & 87.29 & 10. & 163 & 31.12 & 118.68 & 0.33 & 13.42 & - & . \\
\hline P & 11.11 & 1.18 & 48.91 & 7.0 & 160 & 25.31 & 75.40 & 0. & 8.86 & - & - & 19.54 & 1.91 & 76.68 & 10.85 & 133 & 31.73 & 125.62 & 0.17 & 15.10 & -7.1 & -44.6 \\
\hline & & 1.8 & & 7.6 & 1 & 23.50 & 83. & & 11. & - & - & - & 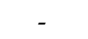 & . & - & 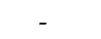 & - & - & 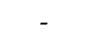 & - & - & . \\
\hline PR_07 & 20.95 & 2.67 & 31.06 & 16.44 & 180 & 45.45 & 70.11 & $<\mathrm{LOD}$ & 1.72 & - & - & 24.92 & 3.56 & 137.75 & 20.02 & 264 & 39.40 & 43.00 & 0.09 & 2.99 & -7.3 & -43.4 \\
\hline & .10 & 1.57 & 58.04 & 10.04 & 190 & 24 & 59.84 & $<\mathrm{LC}$ & 7.6 & - & - & 17. & 2.50 & 110.06 & 11.9 & 196 & 32.95 & 100.60 & 0.18 & 9.20 & -6.8 & -42.4 \\
\hline PR_O & 13.49 & 3.46 & 55.24 & 9.88 & 190 & 16.56 & 59.66 & $<\mathrm{LOD}$ & 4.7 & - & - & 16.56 & 3.84 & 102.96 & 11.09 & 2 & 27.03 & 95.95 & 0.16 & 7.50 & -7.1 & -43.0 \\
\hline dane & 40.02 & 6.39 & 62.3 & 6.7 & 294 & 112.21 & 57.11 & 0.1 & 5.43 & - & - & 47 & 4. & 92.45 & 8.4 & 20 & 94.42 & 41.95 & 0.11 & 6.14 & - & 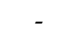 \\
\hline Serchio River & 20.92 & 1.59 & 64.95 & 9.35 & 144 & 29.06 & 97.60 & 0.19 & 11.27 & -8.2 & -48.1 & 15.15 & 1.35 & 58.69 & 8.10 & 153 & 23.03 & 67.27 & 0.11 & 12.30 & -6.5 & -44.2 \\
\hline
\end{tabular}




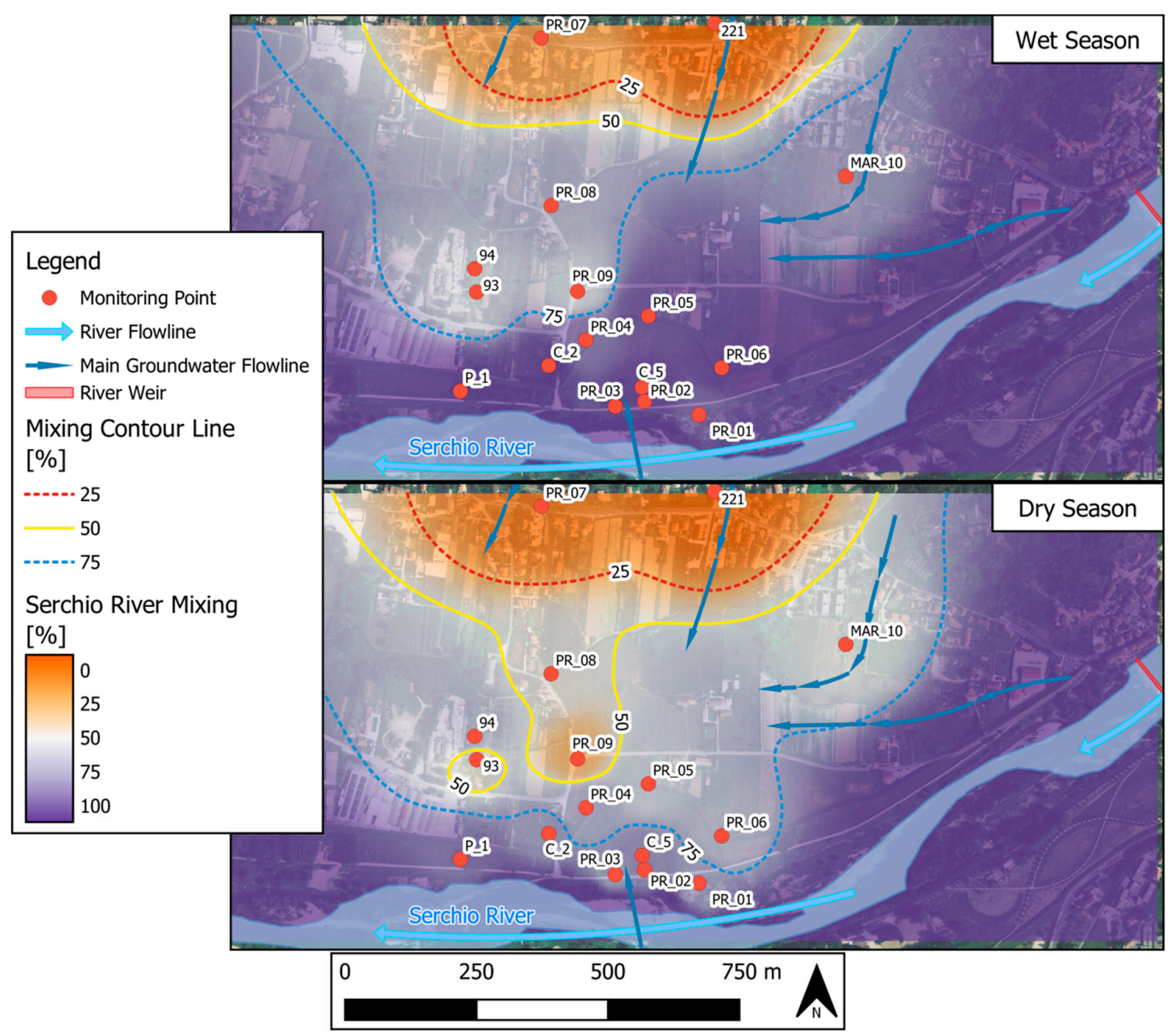

Figure 12. Interpolation showing the Serchio river influence on the Sant'Alessio aquifer and the Serchio River RBF, using lithium as tracer.

These results confirm that the main sources of the RBF pumping wells is the Serchio river water and that the groundwater at the Sant'Alessio plain is mainly characterized by mixing between precipitation occurring in the higher part of the plain and the river water. As an example, the percentage of Serchio river water at the RBF wells ranges from nearly $100 \%$ (during the wet season) to around $80 \%$ (in the dry period), while for the point MAR_10 sample fraction of about $50 \%$ and $70 \%$ of Serchio river water may be estimated for the dry and wet season, respectively (Figure 11). Based on chemical mixing, a precautionary amount of abstracted Serchio river water is estimated to be on average $13.6 \mathrm{Mm}^{3} /$ year, this is $85 \%$ of the total amount of water abstracted in a year $\left(\sim 16 \mathrm{Mm}^{3}\right)$. As such, only the $15 \%\left(2.4 \mathrm{Mm}^{3}\right)$ of abstracted groundwater comes from ambient groundwater.

\section{Conclusions}

In this study, we presented a detailed description of the Serchio River RBF site, and we used a multidisciplinary approach entailing hydrodynamics, hydrochemical, and numerical modelling methods in order to evaluate the change in recharge from the Serchio river to the aquifer due to the building of the RBF infrastructures along the river, and the ratio of bank filtrate to ambient groundwater abstracted at such RBF scheme.

The use of Direct Push technology in combination with traditional site investigation approaches was feasible to provide critical information for reliable characterization of subsurface properties and to inform first the conceptual model and then the implementation of the numerical model. Thereby, the use of DPIL proved successful to produce quantitative information about vertical distribution of 
hydraulic conductivities in a high K environment. Direct Push slug testing as well as tracer testing was successfully used for the in-situ characterization of hydraulic conductivity variations and to capture high flow velocities at the river/aquifer interface in the vicinity of the most western pumping well that were in the order of $\mathrm{m} /$ day.

Our results show that when discussing surface water/groundwater interactions, the Serchio river water constitutes the main source of water for the pumping wells at the RBF scheme. By means of numerical modelling of groundwater flow we simulated the increase in induced recharge, starting from natural conditions, up to present conditions with the Sant'Alessio weir and the vertical wells in full operation. The amount of induced recharge caused by the pumping wells is by far larger than that related to the construction of the Sant'Alessio weir raising the riverbed of about $1.5 \mathrm{~m}$. The weir is however important as it contributes to guarantee a small drawdown in the well-field area. Hydrochemical investigations confirmed and specified the results of the numerical modelling activities. Groundwater at the Sant'Alessio plain is mainly characterized by mixing between precipitation occurring in the higher part of the plain and the river water. This mix seasonally varies depending on the Serchio river discharge, with a marked decrease of the induced component during the Serchio low-flow periods. As an example, the percentage of abstracted Serchio river water at the RBF wells ranges from nearly $100 \%$ (in the wet season) to around $80 \%$ (in the dry season). Based on chemical mixing, a precautionary amount of abstracted Serchio river water is estimated to be on average $13.6 \mathrm{Mm}^{3} /$ year, which is $85 \%$ of the total amount of water abstracted in a year $\left(\sim 16 \mathrm{Mm}^{3}\right)$. Finally, we wish to stress that the assessment of the induced recharge and of the ratio of bank filtrate to ambient groundwater is very important at RBF sites as it may provide relevant insights on the risk of groundwater contamination. This is especially true for the Serchio River RBF as it was already affected by surface water related pollution at the beginning of the 2000 [29]. Disregarding the interactions between surface and groundwater brought to search the cause of contamination in the adjoining agricultural areas and to issue inappropriate local regulations for farming activities [29]. All these issues were discussed in Rodríguez-Escales et al. (2018) [57] in comparison with other MAR sites across the Mediterranean basin: the risk of failure of the Serchio River RBF scheme was defined low. Nowadays, the Serchio River RBF scheme is a reliable site for continuous water supply.

RBF is a worldwide recognized MAR technique for supplying good quality and reliable amounts of water. However, in many cases and countries (including Italy) government authorities do not appear to acknowledge that groundwater extraction is sustained by induced recharge through the river bank and it is not entirely from natural recharge/ambient groundwater. Additionally, several studies take this connection for granted and often only focus on bank filtration treatment capabilities disregarding the amount of recharge induced by the pumping wells. This "induced" component is even not taken into account in the definition of this MAR type in the literature (i.e., [58]). In fact, this remains one of the few MAR schemes where reference to the recharge mechanism is not adequately made in the definition, conversely to, i.e., spreading methods.

Because of this, we suggest to include the term "induced" to complete the definition of this type of MAR technique, hence defining it "Induced RiverBank Filtration". This way we make reference to the fact that the bank filtration is not completely due to natural recharge, as in several cases of natural surface water/groundwater interactions, but it may be partly/almost all human-made.

Author Contributions: Conceptualization, R.R. and T.V.; methodology, R.R., T.V., A.B., C.M.; software, R.R. and G.D.F.; validation, R.R. and T.V.; formal analysis, R.R., A.B., T.V., C.M., G.D.F.; investigation, R.R., A.B., T.V., C.M., G.D.F.; data curation, R.R., A.B., T.V., G.D.F.; writing-original draft preparation, R.R. and A.B.; writing一review and editing, R.R., A.B., T.V., C.M., G.D.F.; visualization, A.B., C.M. and G.D.F.; supervision, R.R.; project administration, R.R. and G.M.; funding acquisition, R.R. All authors have read and agreed to the published version of the manuscript.

Funding: This research was funded by the European Union, Grant Number 619120.

Acknowledgments: The work presented here was performed during the EU co-funded project FP7 MARSOL (Grant Agreement No. 619120). This research also exploited results from the H2020 FREEWAT project, funded by the European Union within the Horizon 2020 research and innovation programme (Grant number 642224). 
Alessio Barbagli (now Department of Physics and Earth Sciences, University of Ferrara, Italy) took part in the research activities during his three-year PhD in Agrobiosciences at the Institute of Life Sciences, Scuola Superiore Sant'Anna. Giovanna De Filippis (now AECOM URS, Milano, Italy) and Chiara Marchina (now Department of Land, Environment, Agriculture and Forestry, University of Padova, Italy) took part to the research activities during a post-doc scholarship at the Institute of Life Sciences, Scuola Superiore Sant'Anna. Thomas Vienken (now also Weihenstephan-Triesdorf University of Applied Sciences, TUM Campus Straubing for Biotechnology and Sustainability, Straubing, Germany) performed these activities while at UFZ. The authors thanks GEAL S.p.a. for the technical support provided and granting access to the well-field during the research activities.

Conflicts of Interest: The authors declare no conflict of interest.

\section{References}

1. WHO; UNICEF. Progress on Drinking Water, Sanitation and Hygiene: Joint Monitoring Programme 2017 Update and SDG Baselines. Available online: http://www.who.int/water_sanitation_health/publications/ jmp-2017/en/ (accessed on 22 October 2020).

2. Meffe, R.; de Bustamante, I. Emerging organic contaminants in surface water and groundwater: A first overview of the situation in Italy. Sci. Total Environ. 2014, 481, 280-295. [CrossRef] [PubMed]

3. Paldor, A.; Shalev, E.; Katz, O.; Aharonov, E. Dynamics of saltwater intrusion and submarine groundwater discharge in confined coastal aquifers: A case study in northern Israel. Hydrogeol. J. 2019, 27, 1611-1625. [CrossRef]

4. Wanner, P. Plastic in agricultural soils-A global risk for groundwater systems and drinking water supplies?-A review. Chemosphere 2021, 264, 128453. [CrossRef] [PubMed]

5. Dillon, P.; Stuyfzand, P.; Grischek, T. Sixty years of global progress in managed aquifer recharge. Hydrogeol. J. 2019, 27, 1-30. [CrossRef]

6. Dillon, P.; Fernández Escalante, E.; Megdal, S.B.; Massmann, G. Managed Aquifer Recharge for Water Resilience. Water 2020, 12, 1846. [CrossRef]

7. Fernandez Escalante, E.; Henao Casas, J.D.; Vidal Medeiros, A.M.; San Sebastián Sauto, J. Regulations and guidelines on water quality requirements for Managed Aquifer Recharge. International comparison. Acque Sotter. Ital. J. Groundw. 2020, 9. [CrossRef]

8. Dillon, P. Future management of aquifer recharge. Hydrogeol. J. 2005, 13, 313-316. [CrossRef]

9. Stefan, C.; Ansems, N. Web-based global inventory of managed aquifer recharge applications. Sustain. Water Resour. Manag. 2018, 4, 153-162. [CrossRef]

10. Umar, D.A.; Ramli, M.F.; Aris, A.Z.; Sulaiman, W.N.A.; Kura, N.U.; Tukur, A.I. An overview assessment of the effectiveness and global popularity of some methods used in measuring riverbank filtration. J. Hydrol. 2017, 550, 497-515. [CrossRef]

11. Kühn, W.; Müller, U. Riverbank filtration. JAWWA 2000, 92, 60-69. [CrossRef]

12. Hiscock, K.M.; Grischek, T. Attenuation of groundwater pollution by bank filtration. J. Hydrol. 2002, 266, 139-144. [CrossRef]

13. Hunt, H.; Schubert, J.; Ray, C. Conceptual Design of Riverbank Filtration Systems. In Riverbank Filtration: Improving Source Water Quality; Springer: Berlin/Heidelberg, Germany, 2002; pp. 19-27.

14. Ray, C. Riverbank Filtration Concepts and Applicability to Desert Environments. In Riverbank Filtration for Water Security in Desert Countries; Springer: Berlin/Heidelberg, Germany, 2011; pp. 1-4.

15. Shankar, V.; Eckert, P.; Ojha, C. Transient three-dimensional modeling of riverbank filtration at Grind well field, Germany. Hydrogeol. J. 2009, 17, 321-326. [CrossRef]

16. Ray, C.; Grischek, T.; Schubert, J.; Wang, Z.; Speth, T.F. A perspective of riverbank filtration. JAWWA 2002, 94, 149-160. [CrossRef]

17. Hoppe-Jones, C.; Oldham, G.; Drewes, J.E. Attenuation of total organic carbon and unregulated trace organic chemicals in U.S. riverbank filtration systems. Water Res. 2010, 44, 4643-4659. [CrossRef] [PubMed]

18. Massmann, G.; Dünnbier, U.; Heberer, T.; Taute, T. Chemosphere Behaviour and redox sensitivity of pharmaceutical residues during bank filtration-Investigation of residues of phenazone-type analgesics. Chemosphere 2008, 71, 1476-1485. [CrossRef] [PubMed]

19. Sprenger, C.; Lorenzen, G.; Hülshoff, I. Vulnerability of bank filtration systems to climate change. Sci. Total Environ. 2011, 409, 655-663. [CrossRef] 
20. Ahmed, A.K.A.; Marhaba, T.F. Review on river bank filtration as an in situ water treatment process. Clean Technol. Environ. Policy 2017, 19, 349-359. [CrossRef]

21. Barthel, R.; Banzhaf, S. Groundwater and Surface Water Interaction at the Regional-scale-A Review with Focus on Regional Integrated Models. Water Resour. Manag. 2016, 30, 1-32. [CrossRef]

22. Cook, P.G. Quantifying river gain and loss at regional scales (Review). J. Hydrol. 2015, 531, 749-758. [CrossRef]

23. Sottani, A.; Vielmo, A. Groundwater conservation and monitoring activities in the middle Brenta River plain (Veneto Region, Northern Italy): Preliminary results about aquifer recharge. Acque Sotter. Ital. J. Groundw. 2014, 3. [CrossRef]

24. Wang, W.-S.; Oswald, S.E.; Gräff, T.; Lensing, H.-J.; Liu, T.; Strasser, D.; Munz, M. Impact of river reconstruction on groundwater flow during bank filtration assessed by transient three-dimensional modelling of flow and heat transport. Hydrogeol. J. 2020, 28, 723-743. [CrossRef]

25. Barbagli, A.; Jensen, B.N.; Raza, M.; Schueth, C.; Rossetto, R. Assessment of soil buffer capacity on nutrients and pharmaceuticals in nature-based solution applications. Environ. Sci. Pollut. Res. 2019, 26, 759-774. [CrossRef] [PubMed]

26. Rossetto, R.; Barbagli, A.; Borsi, I.; Mazzanti, G.; Vienken, T.; Bonari, E. Site investigation and design of the monitoring system at the Sant'Alessio Induced RiverBank Filtration plant (Lucca, Italy). Rend. Online Soc. Geol. Ital. 2015, 35, 248-251. [CrossRef]

27. Studio Nolledi. Indagini Idrogeologiche Finalizzate All'individuazione Dell'area di Salvaguardia del Campo Pozzi di sant'Alessio-Lucca Art. 21 del D.Lgs. 152/99. Prima Fase Individuazione e Caratterizzazione Dell'area di Rispetto. 2003; (Comune di Lucca Unpublished Report). Available online: file://C:/Users/mdpi/ AppData/Local/Temp/D39.pdf (accessed on 7 December 2020).

28. Rossetto, R.; Barbagli, A.; De Filippis, G.; Marchina, C.; Mazzanti, G.; De Caterini, A. Case Study 19: The Serchio River Bank Filtration for Drinking Water Supply in Sant'Alessio area of Lucca, Italy. In Managing Aquifer Recharge: A Showcase for Resilience and Sustainability; Zheng, Y., Ross, A., Villholth, K.G., Dillon, P., Eds.; A Unesco-Iah-Gripp Publication, 2002; (to be Advised). Available online: https://recharge.iah.org/ unesco-exemplary-mar-projects-booklet (accessed on 8 December 2020).

29. Rossetto, R.; Bockelmann-Evans, B. Modellazione numerica del flusso e del trasporto di soluti ai fini dell'investigazione dei processi di trasporto dell'erbicida terbutilazina nel sistema acquifero della pianura di S. Alessio (Lucca). G. Geol. Appl. 2007, 5, 29-44.

30. EPA. Expedited Site Assessment Tools for underground Storage Tank Sites. A Guide for Regulators; U.S. Government Printing Office: Washington, DC, USA, 1997.

31. Butler, J.J. Hydrogeological Methods for estimation of Spatial Variations in Hydraulic Conductivity. In Hydrogeophysics; Rubin, Y., Hubbard, S.S., Eds.; Springer: Berlin/Heidelberg, Germany, 2005; pp. $23-58$.

32. Dietrich, P.; Leven, C. Direct Push-Technologies. In Groundwater Geophysics; Kirsch, R., Ed.; Springer: Berlin/Heidelberg, Germany, 2006; pp. 321-340.

33. McCall, W.; Nielsen, D.M.; Farrington, S.P.; Christy, T.M. Use of Direct-Push Technologies in Environmental Site Characterization and Ground-Water Monitoring. In Practical Handbook of Environmental Site Characterization and Ground-Water Monitoring; Nielsen, D.M., Ed.; CRC Press Taylor and Francis Group: Boca Raton, FL, USA, 2006; pp. 345-471.

34. Liu, G.S.; Butler, J.J.; Reboulet, E.; Knobbe, S. Hydraulic conductivity profiling with direct push methods. Grundwasser 2012, 17, 19-29. [CrossRef]

35. Vienken, T.; Leven, C.; Dietrich, P. Use of CPT and other direct push methods for (hydro-) stratigraphic aquifer characterization-A field study. Can. Geotech. J. 2012, 49, 197-206. [CrossRef]

36. Vienken, T.; Kreck, M.; Hausmann, J.; Werban, U.; Dietrich, P. Innovative strategies for high resolution site characterization: Application to a flood plain. Ital. J. Groundw. 2014, 138, 7-14. [CrossRef]

37. Dietrich, P.; Butler, J.J.; Faiss, K. A rapid method for hydraulic profiling in unconsolidated formations. Ground Water 2008, 46, 323-328. [CrossRef]

38. Sellwood, S.M.; Healey, J.M.; Birk, S.; Butler, J.J. Direct-push hydrostratigraphic profiling: Coupling electrical logging and slug tests. Ground Water 2005, 43, 19-29. [CrossRef]

39. Vienken, T.; Huber, E.; Kreck, M.; Huggenberger, P.; Dietrich, P. How to chase a tracer-Combining conventional salt tracer testing and direct push electrical conductivity profiling for enhanced aquifer characterization. Adv. Water Resour. 2017, 99, 60-66. [CrossRef] 
40. Marchina, C.; Zuecco, G.; Chiogna, G.; Bianchini, G.; Carturan, L.; Comiti, F.; Engel, M.; Natali, C.; Borga, M.; Penna, D. Alternative methods to determine the $\delta^{2} \mathrm{H}-\delta^{18} \mathrm{O}$ relationship: An application to different water types. J. Hydrol. 2020, 587, 124951. [CrossRef]

41. De Filippis, G.; Borsi, I.; Foglia, L.; Cannata, M.; Velasco Mansilla, V.; Vasquez-Suñe, E.; Ghetta, M.; Rossetto, R. Software tools for sustainable water resources management: The GIS-integrated FREEWAT platform. Rend. Online Soc. Geol. 2017, 42, 59-61. [CrossRef]

42. Foglia, L.; Borsi, I.; Mehl, S.; De Filippis, G.; Cannata, M.; Vasquez-Sune, E.; Criollo, R.; Rossetto, R. Freewat, A Free and Open Source, GIS-Integrated, Hydrological Modeling Platform. Groundwater 2018, 56, 521-523. [CrossRef] [PubMed]

43. Harbaugh, A.W. MODFLOW-2005, The U.S. Geological Survey Modular Ground-Water Model-The Ground-Water Flow Process; Techniques and Methods 6-A16; U.S. Geological Survey: Reston, VA, USA, 2005. [CrossRef]

44. Rossetto, R.; Borsi, I.; Schifani, C.; Bonari, E.; Mogorovich, P.; Primicerio, M. SID\&GRID: Integrating hydrological modeling in GIS environment. Rend. Online Soc. Geol. Ital. 2013, 24, 282-283.

45. Rossetto, R.; Borsi, I.; Foglia, L. Freewat: Free and open source software tools for WATer resource management. Rend. Online Soc. Geol. Ital. 2015, 35, 252-255. [CrossRef]

46. Criollo, R.; Velasco, V.; Nardi, A.; Vries, L.M.; Riera, C.; Scheiber, L.; Jurado, A.; Brouyère, S.; Pujades, E.; Rossetto, R.; et al. AkvaGIS: An open source tool for water quantity and quality management. Comput. Geosci. 2020, 127, 123-132. [CrossRef]

47. Cannata, M.; Neumann, J.; Rossetto, R. Open source GIS platform for water resource modelling: FREEWAT approach in the Lugano Lake. Spat. Inf. Res. 2018, 26, 241-251. [CrossRef]

48. De Filippis, G.; Pouliaris, C.; Kahuda, D.; Vasile, T.A.; Manea, V.A.; Zaun, F.; Panteleit, B.; Dadaser-Celik, F.; Positano, P.; Nannucci, M.S.; et al. Spatial Data Management and Numerical Modelling: Demonstrating the Application of the QGIS-Integrated FREEWAT Platform at 13 Case Studies for Tackling Groundwater Resource Management. Water 2020, 12, 41. [CrossRef]

49. Joodavi, A.; Izady, A.; Karbasi Maroof, M.T.; Majidi, M.; Rossetto, R. Deriving optimal operational policies for off-stream man-made reservoir considering conjunctive use of surface- and groundwater at the Bar dam reservoir (Iran). J. Hydrol. Reg. Stud. 2020, 31, 100725. [CrossRef]

50. La Vigna, F.; Hill, M.C.; Rossetto, R.; Mazza, R. Parameterization, sensitivity analysis, and inversion: An investigation using groundwater modeling of the surface-mined Tivoli-Guidonia basin (Metropolitan City of Rome, Italy). Hydrogeol. J. 2016, 24, 1423-1441. [CrossRef]

51. Rossetto, R.; Barbagli, A.; De Filippis, G.; Marchina, C.; Di Bartolo, S.; Bonari, E.; Sabbatini, T.; Triana, F.; Tozzini, C.; Ercoli, L.; et al. Deliverable 8.4. Report on the Induced RiverBank Filtration MAR Plant at Sant'Alessio (Lucca, Italy). FP7 MARSOL (Demonstrating Managed Aquifer Recharge as a Solution to Water Scarcity and Drought). Available online: http://marsol.eu/ (accessed on 28 November 2020).

52. Butler, J.J., Jr.; Garnett, E.J.; Healey, J.M. Analysis of Slug Tests in Formations of High Hydraulic Conductivity. Groundwater 2003, 41, 620-631. [CrossRef] [PubMed]

53. Barbagli, A. Analysis of Water-Soil Interaction in Drainage Water Phyto-Treatment and in Aquifer Recharge Schemes. Ph.D. Thesis, Scuola Superiore Sant'Anna, Pisa, Italy. Available online: https://dta.santannapisa.it (accessed on 28 November 2020).

54. Rozanski, K.; Araguás-Araguás, L.; Gonfiantini, R. Isotopic Patterns in Modern Global Precipitation, in Climate Change in Continental Isotopic Records; Swart, P.K., Lohmann, K.C., Mckenzie, J., Savin, S., Eds.; American Geophysical Union: Washington, DC, USA, 1993. [CrossRef]

55. Longinelli, A.; Selmo, E. Isotopic composition of precipitation in Italy: A first overall map. J. Hydrol. 2003, 270, 75-88.

56. La Ruffa, G.; Panichi, C. Caratterizzazione Chimico-Isotopica Delle Acque Fluviali: Il Caso Del Fiume Arno; Istituti Editoriali Poligrafici Internazionali: Pisa, Italy, 2000; p. 101.

57. Rodríguez-Escales, P.; Canelles, A.; Sanchez-Vila, X.; Folch, A.; Kurtzman, D.; Rossetto, R.; Fernández-Escalante, E.; Lobo-Ferreira, J.P.; Sapiano, M.; San-Sebastián, J.; et al. A risk assessment methodology to evaluate the risk failure of managed aquifer recharge in the Mediterranean Basin. Hydrol. Earth Syst. Sci. 2018, 22, 3213-3227. [CrossRef] 
58. Natural Resource Management Ministerial Council, Environment Protection and Heritage Council National Health and Medical Research Council. Australian Guidelines for Water Recycling, Managing Health and Environmental Risks, Vol 2C: Managed Aquifer Recharge. Available online: http: //webarchive.nla.gov.au/gov/20130904195601/http://www.environment.gov.au/water/publications/quality/ water-recycling-guidelines-mar-24.html (accessed on 29 September 2020).

Publisher's Note: MDPI stays neutral with regard to jurisdictional claims in published maps and institutional affiliations.

(C) 2020 by the authors. Licensee MDPI, Basel, Switzerland. This article is an open access article distributed under the terms and conditions of the Creative Commons Attribution (CC BY) license (http://creativecommons.org/licenses/by/4.0/). 